\title{
Multi-axis force sensors: a state-of-the-art review
}

\author{
Jack O. Templeman ${ }^{1}$, Brian B. Sheil ${ }^{1}$ and Tong Sun ${ }^{2}$
}

${ }^{1}$ Department of Engineering Science, University of Oxford, Parks Road, Oxford OX1 3PJ, UK.

${ }^{2}$ City, University of London, Northampton Square, London EC1V 0HB, UK.

Main text wordcount: 4980

Figures: 19

Tables: 4

Initial submission, 20 May 2019

Revised submission, 10 November 2019 


\section{INTRODUCTION}

2 Sensors capable of measuring multi-directional force, moment or combinations thereof are popular

3 in a wide range of engineering research, including automation, machining processes, aerospace,

4 medical applications and civil engineering. In this way, a single multi-axis sensor can perform what

5 is essentially a three-dimensional (3D) measurement of physical quantities. These sensors are

6 designed to produce an output signal in response to stimulation from a physical system of multiple

7 force and moment components. In the vast majority of multi-axis force sensors this is achieved by

8 using multiple strain-sensitive elements mounted on an elastic structure. The sensor structure is

9 fundamental in determining important characteristics of the sensor such as stiffness, measurement

10 range and isotropy, and any undesirable coupling between sensor outputs. Both the sensitive elements

11 and the elastic structure require careful consideration to design a force sensor for accuracy, reliability

12 and robustness.

13 The development of multi-axis force sensors has been considered extensively in the literature over

14 the past seven decades. Furthermore, these sensors have been developed for widely varying

15 requirements and conditions due to the broad range of potential applications. However, a collective

16 resource which collates and examines this information does not exist. This paper presents a state-of-

17 the-art review of multi-axis force sensing and sensor development. The basic concepts of force

18 sensing and the adopted generalized framework are introduced. The fundamental strain sensing

19 techniques adopted for the sensitive elements most commonly reported in the literature are also

20 explored. Finally, a critical review of a large number of elastic structure designs is presented, broadly

21 categorised as follows: (a) three degrees-of-freedom (DOF) cross-beam, (b) six DOF cross-beam, (c)

22 column-type, (d) beam-column type and (e) Stewart platform. 
24 The system considered in this paper is defined in Figure 1. Convention defines the $x$ and $y$ axes in the 25 plane of the sensor (lateral direction) and the $z$ axis in the out-of-plane (vertical) direction. Therefore $F_{\mathrm{z}}$ and $M_{\mathrm{z}}$ denote axial force and moment respectively, $F_{\mathrm{x}}$ and $F_{\mathrm{y}}$ denote mutually orthogonal lateral forces and $M_{\mathrm{x}}$ and $M_{\mathrm{y}}$ denote mutually orthogonal lateral moments. The $n$ force components may be assembled into a force vector $\boldsymbol{f}$ which, in the most general case, can be defined as:

$$
\boldsymbol{f}=\left[\begin{array}{llllll}
F_{\mathrm{x}} & F_{\mathrm{y}} & F_{\mathrm{z}} & M_{\mathrm{x}} & M_{\mathrm{y}} & M_{\mathrm{z}}
\end{array}\right]^{\mathrm{T}}
$$

29 The respective outputs produced by the individual strain transducers within the sensor may be defined 30 as an output vector $\boldsymbol{u}$ as follows:

$$
\boldsymbol{u}=\left[\begin{array}{lllll}
u_{1} & u_{2} & u_{3} & \ldots & u_{\mathrm{m}}
\end{array}\right]^{\mathrm{T}}
$$

31 where $u_{\mathrm{i}}$ denotes the output from the $i$ th transducer and $m$ is the total number of strain transducers.

32 The relationship between the force and output vectors is therefore given by the matrix equation

$$
\boldsymbol{u}=\boldsymbol{C f}
$$

33 where $\boldsymbol{C}$ is an $m \times n$ 'compliance matrix'. Although $\boldsymbol{C}$ can be determined analytically or numerically, 34 it is most commonly determined experimentally through calibration tests (e.g. [1-3]). In a fully 35 decoupled sensor, each output responds only to the application of a single corresponding load 36 component. Coupling within a sensor, often referred to as 'crosstalk', means there are cross37 sensitivities between the different channels such that the application of a particular load component 38 influences multiple output signals. 


\section{Electrical resistance strain gauging}

41 Electrical resistance strain gauges (ERSGs) operate on the principle of an electrical conductor undergoing a change in electrical resistance due to geometry change. To obtain measurable output signals from the small resistance changes associated with ERSGs, they are commonly arranged in Wheatstone bridge circuits. This also facilitates temperature compensation where thermal-induced resistance changes apply to each arm of the bridge thereby mitigating any influence on the aggregated circuit output. A limitation of this sensing technology is vulnerability to electromagnetic (EM) interference and damage arising from water ingress into the sensor. ERSGs also have relatively low sensitivity, which can be a limitation in applications where a large sensor stiffness is required.

Fibre Bragg gratings

Although a number of optical strain measurement methods exist (e.g. Fabry-Perot interferometers, Rayleigh and Brillouin scattering), Fibre Bragg Gratings (FBGs) are the most popular for force measurement applications. FBGs are created by forming a periodic modulation of the refractive index

53 along the core of a single-mode optical fibre. When a broadband spectrum of light is incident on an

54 FBG within a fibre, a narrow band of the spectrum is reflected through coherent scattering at the grating index variations, as shown in Figure 2 [4,5]. The reflected spectrum is characterised by the Bragg wavelength, $\lambda_{\mathrm{B}}$, which is defined as

$$
\lambda_{\mathrm{B}}=2 n_{\mathrm{eff}} \Lambda
$$

57 where $n_{\text {eff }}$ is the mode effective refractive index and $\Lambda$ is the grating period. If an FBG is mounted to

58 a structure the change in wavelength, $\Delta \lambda_{\mathrm{B}}$, can be related to strain, $\epsilon$, or the change in temperature, $59 \Delta T$, using the equation given in [6]: 


$$
\frac{\Delta \lambda_{\mathrm{B}}}{\lambda_{\mathrm{B}}}=\left(1-P_{\mathrm{e}}\right) \epsilon+\left(\alpha+\zeta+\left(1-P_{\mathrm{e}}\right)\left(\alpha_{\mathrm{s}}-\alpha\right)\right) \Delta T
$$

60 where $\alpha$ and $\alpha_{\mathrm{s}}$ are the thermal expansion coefficients of the fibre and sensor structure respectively,

61 and $P_{\mathrm{e}}$ and $\zeta$ are the photo-elastic and thermal-optic coefficients respectively of the fibre core.

62 Temperature compensation remains one of the major obstacles in the use of FBGs for force sensing.

63 One of the most common methods is the use of a reference 'strain-free' FBG (e.g. [7]). However, a 64 range of alternatives feature in the literature including dual-wavelength superimposed FBGs [8], dualdiameter FBGs $[9,10]$ and the combination of an FBG with other structures, including long-period gratings [11], polarization-rocking filters [12] and superstructure FBGs [13]. Arguably one of the most effective methods is to perform arithmetic operations on two or more FBG measurements in a similar manner to that of a Wheatstone bridge (e.g. [14-16]). The use of FBGs as a strain sensing technology is desirable due to high sensitivity, immunity to EM interference and water damage and the ability to multiplex large numbers of FBGs along a single fibre. The comparatively high cost of

71 FBG sensing compared to ERSGs, particularly with respect to optical interrogators, has slowed its adoption into broad industrial sectors however.

\section{Semiconductor strain gauges}

74 Semiconductor strain gauges (SSGs) are formed from a semiconducting material, most commonly silicon [17]. SSGs operate using the piezoresistive effect, which refers to the dependence of the electrical resistivity of a material on mechanical strain [18]. For a conductor subjected to a longitudinal strain $\epsilon$, the gauge factor (GF) can be defined as

$$
\mathrm{GF}=1+2 v+\left(\frac{1}{\epsilon} \frac{\Delta \rho}{\rho}\right)
$$

78 where $v$ is the Poisson's ratio of the conductor material and $\rho$ is the material resistivity which undergoes a change of $\Delta \rho$ [17-19]. The first two terms in Equation (6) correspond to the resistance 
change due to changes in the conductor geometry, while the last term corresponds to change in the conductor material resistivity [18,19]. SSGs typically have a significantly greater strain sensitivity than metallic strain gauges, due to the greater change in resistivity under strain [20]. However, one of the most important applications of SSGs is in Micro-electro-mechanical systems (MEMS) force sensors, as micro-machining techniques allow them to be constructed at a much smaller scale.

\section{Capacitive sensing}

A capacitor is a component comprising electrical conductors separated by a non-conductive layer formed from a dielectric medium. When a potential difference is applied to the capacitor, an electric field is induced across the dielectric layer. This produces a net positive electrical charge developing on one conductor and a net negative charge on the other. For a simple capacitor consisting of two parallel plates of cross-sectional area $A$, separated by a uniform gap of thickness $d$, the capacitance, $C$, is given by

$$
C=\frac{\epsilon_{0} \epsilon_{\mathrm{r}} A}{d}
$$

where $\epsilon_{0}$ and $\epsilon_{\mathrm{r}}$ are the permittivity of free space and dielectric material forming the gap respectively and $d \ll A$. Capacitive sensing can achieve high sensitivity, allowing measurement of very small deflections [21]. Similar to SSGs, capacitors can be created through micro-machining techniques, facilitating very small-scale force measurement. Capacitive sensing also allows the creation of flexible sensors, which has led to their adoption in measuring tactile information [22].

\section{THREE DOF CROSS-BEAM SENSORS}

One of the most widely adopted multi-axis force sensor designs is the 'cross-beam' or 'Maltese cross' type. This design typically consists of an outer frame connected to a central platform by three or more elastic beam members. The most common arrangement comprises four beams arranged in a planar 
cross-shape, as illustrated in Figure 3. In this case, application of an in-plane force, such as $F_{\mathrm{x}}$ and / or $F_{\mathrm{y}}$, induces axial deformation in the members parallel to the load, as well as lateral bending in the members perpendicular to the load. Application of an axial force $F_{\mathrm{z}}$ and moment $M_{\mathrm{z}}$ induce out-ofplane bending and lateral bending respectively in all four members. Lateral moments $M_{\mathrm{x}}$ and $/$ or $M_{\mathrm{y}}$ induce vertical bending and torsion in the members perpendicular and parallel to the moment axis respectively. Collinearity between the $x$ and $y$ loading directions and the elastic beams in a four-spoke beam design assists decoupling of sensor outputs and maximises the strain in the beams, whilst also achieving an identical response for mutually orthogonal lateral forces and moments. Table 1 presents a comprehensive list of three DOF force sensors documented in the literature. Only the salient studies are discussed in further detail below. The three DOF load combinations that have been considered in the literature are as follows:

(a) $F_{\mathrm{x}}, F_{\mathrm{y}}, F_{\mathrm{z}}(3 \mathrm{DOF}-\mathrm{A})$ : the upper and lower surfaces of the elastic beams are instrumented, which are typically designed with low vertical bending resistance. $F_{\mathrm{x}}$ and $F_{\mathrm{y}}$ are generally applied at a vertical offset to the cross centre, such that they induce out-of-plane bending.

(b) $F_{\mathrm{x}}, F_{\mathrm{y}}, M_{\mathrm{z}}$ (3DOF-B): the lateral surfaces of the elastic beams are instrumented, which are

Valdastri et al. [23] presented a piezoresistive 'micro' 3DOF-A cross-beam design. The force 119 components are applied to the sensor at a fixed vertical offset via a rigid rod attached to the central 120 platform. Measurement of the out of-plane deformations of the cross-beams was used to resolve the 121 applied lateral forces. The cross-beam structure is etched from silicon wafer with one p-type silicon 122 piezoresistor per beam, obtained via ion implantation, arranged in four quarter Wheatstone bridge 123 circuits. Fontana et al. [24] described a larger scale 3DOF-A cross-beam design operating on similar 124 principles, except using four Wheatstone bridges comprising 16 ERSGs. Bekhti et al. [25] 
documented a miniature 3DOF-A design employing capacitive sensing. A plastic cross-beam was mounted on a conductive plate and supported above a printed circuit board (PCB), forming four capacitors in a square grid. Each of the four beam members was formed from two compliant laterallyspaced beams as shown in Figure 4. Xiong et al. [26] proposed a 3DOF-A cross-beam sensor for robot plantar force measurement, using a total of five FBGs for strain sensing (see Figure 5). Decoupling of measurements and temperature compensation were achieved by forming each sensor output as the difference between two FBG wavelength shifts.

Kim et al. [27] presented a 3DOF-B sensor in which the beams were laterally-compliant. The novelty of this design is centred around the use of additional compliant beams in the outer frame, to promote decoupling of sensor output (see Figure 6). The compliant elements were instrumented with a total of 40 ERSGs. Fernandez Fernandez et al. [14] documented a 3DOF-C sensor applied to the control of robots in 'EM noisy environments'. Those authors adopted a classic rigid four-beam structure, resembling that shown in Figure 3, instrumented with eight FBGs. The sensor outputs were created by taking the difference between the wavelength shifts of the FBGs on opposite sides of each beam; this had the added advantage of achieving temperature compensation.

\section{SIX DOF CROSS-BEAM SENSORS}

\section{Rigid jointed cross-beams}

Six DOF cross-beam force sensors typically require strain-sensing elements on all sides of the elastic members [28]. To achieve similar lateral and vertical compliance, square beam cross-sections are common [24]. In its most rudimentary form, a six DOF cross-beam comprises rigid frame-beam and platform-beam joints. Table 2 provides a broad list of six DOF cross-beam sensors documented in the literature. Chao and Yin [3] adopted a design similar to that presented in Figure 3 to measure the reaction load on a human foot during locomotion. However, the use of rigid joints was shown to 
reduce measurement isotropy and measurements also showed a high degree of coupling [29,30]. Kim et al. [31] presented a cross-type design in which grooves were machined into the beams to incorporate capacitive sensing, as shown in Figure 7. Each groove was filled with dielectric elastomer positioned between two conductive electrodes. Application of a load to the central platform causes a contraction of the grooves thereby altering the capacitance of the sensing elements. Palli et al. [32] proposed a cross-beam design coupled with optoelectronic sensing. In this design, deflection of the cross-beam is measured by changes in the light received by a series of photodetectors from light emitting diodes through relative movement of a reflective surface. Although less common, Lin et al. [33] and Feng et al. [34] proposed 'double-cross' designs using eight elastic beam elements for wheel force measurement (see Figure 8). The redundant spokes provided additional structural capacity. The 3DOF-B design proposed by [33] was extended in [34] to 6DOF measurement by placing additional strain-sensitive elements on the top and bottom surfaces of the eight beams.

\section{Flexible jointed cross-beams}

The use of flexible elements in the outer frame has featured frequently in the literature to minimise coupling between sensor outputs. Flexible frame-beam joints are analogous to sliding universal joints when compliance in three DOF is introduced, namely displacement parallel to the beam axis and rotation about two mutually orthogonal axes, both of which are perpendicular to the beam axis [28]. This allows the sensor body to be manufactured monolithically but does not introduce any undesirable behaviours associated with mechanical connections, such as friction and clearances.

Scheinman [35] documented one of the earliest designs of this type for use in wrist force sensing, described later in detail in [36]. This cross-beam design features thin flexures machined into the outer frame at the frame-beam joints. The four cross-beam members were instrumented with 16 SSGs (one placed on all surfaces of each beam). A similar design was presented by Van Brussel et al. [37] using ERSGs, as shown in Figure 9. The flexures were dimensioned to simulate ball-hinge behaviour. Chao 
and Chen [38] modified the traditional cross-beam design to include ball-bearings at the frame-beam joints (see Figure 10). The design was shown to have high sensitivity and significantly improved measurement isotropy compared to an equivalent fixed-joint design. Dao et al. [39] documented a micro cross-beam sensor using piezoresistive strain-sensing for measuring the fluctuating force and moment components on a particle at the bed of a turbulent channel flow. The cross-beam was fabricated on a micro sensing chip from n-type silicon using a micromachining process. Eighteen piezoresistors formed using impurity diffusion were located on the upper surface of the beams. Shi and Hall [40] presented a cross-beam wheel force sensor using radial spherical plain bearings at the frame-beam joints. Compared with the design in [38], this design freed the three rotational DOF and the radial displacement at the frame-beam joints. Ma and Song [41] developed a simplified analytical model of a cross-beam with compliant frame elements using Timoshenko beam theory, to explore the strain distributions along the elastic beams.

The design documented by Kim [42] uses 'parallel-plate beams' in the outer frame to achieve lower deflection and rotation due to bending moment and axial moment respectively. Kim et al. [43] documented an extension of this design in which the beam members are also modified. Each beam contained both a vertically and laterally compliant parallel-plate-beam. Both versions of this sensor required 24 ERSGs. A significantly more complex structure was documented by Mastinu et al. [44] and Gobbi et al. [45] involving a three-spoked design with 'sliding spherical joints' at the frame-beam joints. The joints are designed to allow four DOF: three rotations and displacement parallel to the beam axis. Mastinu et al. [44] documented the design development of this sensor whereas Gobbi et al. [45] presented the sensor construction and experimental assessment. The design demonstrated good linearity and a maximum coupling error of $<1 \%$. Sun et al. [46] presented another force sensor in which the outer frame contained highly-compliant plates (see Figure 11). To increase sensitivity, each cross-member contains a single vertically-orientated blind hole and is instrumented to measure 3DOF-B loads. Similarly, the frame contains horizontally-orientated through-holes and are 
197 instrumented for measurement of 3DOF-C loads. The frame also contains thin, laterally compliant 198 plates to connect the structure to the fixed corner points. Interestingly, the layout of the ERSGs on 199 the cross-beams differ to that typically adopted in the literature in that they are orientated in the shear 200 direction i.e. at $45^{\circ}$ to the beam axis.

201 Kang et al. [30] undertook an optimization exercise using finite element analysis to minimise coupling 202 error in a six DOF cross-beam sensor. For the purpose of this review, the deformed shape of this 203 sensor subjected to $F_{\mathrm{z}}, F_{\mathrm{y}}, M_{\mathrm{z}}$ and $M_{\mathrm{x}}$ loading was explored using a Solidworks 2019 (perfectly204 elastic) finite element analysis (FEA). The results are presented in Figure 12 where contours indicate 205 the magnitude of the resultant displacements. Although these results are only indicative, it can be 206 seen that significant deformations occur at the flexible joints. It was demonstrated in [30] that this 207 flexible joint behaviour achieved a coupling error of $<3.2 \%$, determined using both numerical 208 analysis and experimental testing. Kazerooni and Akbari [47] progressed this work by proposing a 209 modified optimization formulation to reduce the coupling error to $<1.5 \%$. Similar designs include 210 the sensor documented by Schickl et al. [48] for use in measurement of forces in the feet of humanoid 211 robots and the large sensor documented by Chen et al. [49] for robotic manipulator control in space 212 applications. Huang et al. [50] presented analysis of a very similar sensor structure to in [30], except 213 instrumented with a total of 16 FBGs, with one placed on each side of the four cross beams. Similar 214 to the design in [14], the sensor outputs were formed from the wavelength shift difference between 215 FBGs on opposite sides of each beam, which also achieves temperature compensation. The $8 \times 6$ 216 compliance matrix for this design was determined using both 3D FEA and an analytical Timoshenko 217 beam theory model developed in [51].

219 These sensors involve a vertical assembly of two cross-beam sensors, where each cross-beam is 220 tasked with the measurement of a specific three DOF load combination. The design documented by 
221 Kim et al. [52] combined the 3DOF-B load cell reported in Kim et al. [27] (shown in Figure 6) with 222 a lower 3DOF-C cross-beam. The two cross-beams are connected through the outer frames and were 223 instrumented with ERSGs. In the dual sensor proposed by Yuan et al. [53], an upper 3DOF-B and a 224 lower 3DOF-C cross-beam are connected via the central platforms. Rigid frame-beam joints with 225 vertically compliant beams were adopted for the upper cross-beam with a total of eight ERSGs on the 226 upper and lower surfaces of the beams. The lower cross beam comprised flexible frame-beam joints 227 and laterally-compliant beam elements featuring a total of eight ERSGs mounted on the beam side 228 surfaces. Wu and Cai [54] proposed a dual-layer cross-beam involving an upper 3DOF-B and a lower 229 3DOF-C. The beam ends were located within grooves in an outer cylindrical shell as shown in Figure 230 13. Each beam contains a 'double-hole' to create a double bending-beam. Although the sliding frame231 beam joints were intended to decouple sensor outputs, those authors noted that very accurate sliding 232 clearances were required to achieve this.

\section{COLUMN-TYPE SENSORS}

234 Column-type sensors typically feature an elastic body made of a single prismatic element which is 235 fixed at one end and free to deflect and rotate at the other. Loads applied to the sensor at the free end 236 induce a strain field in the elastic body which is measured by various combinations of strain-sensitive 237 elements. The most commonly-adopted column-type load cell design features a cylindrical elastic 238 body, such as that shown in Figure 14. Typically only the outside surface is instrumented, as it 239 experiences the greatest strains and mounting the strain sensing elements is more straightforward.

240 Table 3 provides a summary of column-type sensors that have featured in the literature. The main 241 advantages of the column-type are its simplicity and robustness. Column-type sensors also exhibit 242 significantly greater stiffness in the vertical direction compared to cross-beam sensors [55]. The main 243 disadvantage associated with these sensors is poor measurement isotropy and low sensitivity to $F_{\mathrm{z}}$. In 244 particular, there are unavoidable couplings between the measurements of lateral forces and lateral 
moments. The column also needs to be sufficiently long to ensure strain sensing elements are not located within the non-uniform strain distributions towards the ends.

247 The earliest column-type designs referenced in the literature are related to biomechanics applications. 248 Cunningham and Brown [56] presented a method for the measurement of human gait involving a 249 rectangular plate supported by four column-type load cells at the corners. The columns were tubular 250 cylinders, machined from a solid bar, with ERSGs mounted on the outside surface. End flanges 251 enabled bolted connections to the plate and base. Paul [57] reported similar force plate designs to that 252 in [56] except each column was instrumented with twelve silicon SSGs rather than ERSGs. The SSGs 253 were arranged in three layers along the length of the column and formed six bridge circuit outputs for 254 the six load components acting on the force plate. Berme et al. [1] presented a reduced-length design to facilitate inclusion within the pylon of a prosthesis. Instead of deriving the lateral forces using the difference in bending moment at two axial positions, the shear forces were measured directly using strain gauges orientated $\pm 45^{\circ}$ to the cylinder axis. Van Brussel et al. [37] presented a six-axis design consisting of two rigid rings connected by four vertical flexural strips. The design resembles a cylindrical column with four large sections at the cardinal points of the wall removed. 3DOF-B loads are related to the shear strain in the flexural strips, whereas 3DOF-C loads are obtained from the bending and compression strains. Byrne and Houlsby [2] used a column-type load cell design for the measurement of six DOF loading applied to a model foundation on sand (see Figure 14). A total of 26332 ERSGs were bonded to the outer surface of the cylinder in groups of four and positioned at eight 264 circumferential locations. This provided six full Wheatstone bridge circuits corresponding to each of the six DOF load components. Van der Laag [15] extended this work to develop a sensor employing a combination of both ERSGs and FBGs. 32 ERSGs were mounted on the outside surface to form 267 eight full Wheatstone bridges whereas 32 and 14 FBGs were located on the outer and inner surfaces respectively. Arithmetic operations performed on the outputs of two or more FBGs, in a similar manner to Wheatstone bridge circuits, were used to achieve load and temperature isolation. That 
270

271 FBGs to the sensor structure were identified.

\section{BEAM-COLUMN SENSORS}

273

Although much less common, beam-column force sensors generally consist of both elastic beam and column elements that undergo deformation during loading. Stroud [58] documented one of the more popular designs of this type which was later described in greater detail by Bransby [59] (see Figure 15). The design features four vertical columns and four horizontal beams which connect an upper and lower 'block'. The columns and beams are designed to be flexible in bending. $F_{\mathrm{z}}$ induces axial compression in the vertical columns whereas $F_{\mathrm{x}}$ induces tension in one pair of horizontal beams and compression in the other pair [59]. ERSGs are mounted on both faces of all eight elastic elements to form three Wheatstone bridge circuits. Huang et al. [60] proposed a robot wrist force sensor using a cross-beam supported by four vertical beams connected to an outer frame, as shown in Figure 16. Lateral forces and axial moment are measured by bending deformation of the vertical beams using ERSGs. The lateral moments and axial force are measured through conventional out-of-plane bending of the cross members.

\section{STEWART PLATFORM SENSORS}

Stewart [61] originally described the Stewart platform as a six DOF mechanism, consisting of a rigid plate (referred to as the platform) which is connected to a fixed base by six legs, as shown in Figure 17. The legs are formed from elastic members which can be instrumented to measure load-induced axial deformations. Stewart platform sensors generally have the characteristics of high stiffness and load capacity, through distributing the loading axially over the six legs. To achieve a six DOF mechanism, at least one spherical joint is required on each leg whereas the other joint can be either a universal or spherical joint [62]. To convert the Stewart platform into a force sensor, the same joint 
configuration is required to ensure that the deformations in the legs are purely axial. A summary of

294 Stewart platform force sensors documented in the literature is given in Table 4.

295 Romiti and Sorli [63] presented an early six DOF Stewart platform force sensor using six single-axis 296 force sensors as platform legs. The legs were connected to the two platforms via low-friction ball 297 joints. Sorli and Zhmud [64] and Ferraresi et al. [65] subsequently developed a prototype of this 298 design where experimental investigations revealed a very high stiffness to the applied loads. 299 However, hysteresis and non-linearity was observed in the sensor output due to backlash in the ball 300 joints [64]. Dai and Kerr [66] proposed using six pre-tensioned flexible wire legs to ensure transferral 301 of axial forces only. The force in each wire was measured using six elastic cantilevers fixed to the sensor base, instrumented with ERSGs. Kang [62] proposed platform legs comprising two springs 303 located at either end of a 'core'. A linear variable differential transformer (LVDT) was mounted on 304 each leg to measure axial deflections under the applied loads. The legs were connected to the base 305 and platform using ball and socket joints. Dwarakanath et al. [67] documented a Stewart platform 306 design employing bending rings in the sensor legs (see Figure 18). The rings introduced compliance 307 into the system and facilitated concentration of strain. However, some inaccuracies and repeatability 308 issues were encountered arising from clearances in the ball and socket joints used to connect the legs 309 to the platform and base.

310 Zhenlin et al. [68] presented a parallel mechanism force sensor described as a variant on the Stewart 311 platform. Six elastic legs, arranged in three pairs, were used to connect three orthogonal sides of a 312 cube-shaped platform to the base. A monolithic structure was possible by adopting flexural hinges 313 instead of the traditional spherical joints. This structure showed improved measurement isotropy over 314 the traditional Stewart platform structure geometry. Ranganath et al. [69] and Bhavikatti et al. [70] 315 proposed using Stewart platform-type geometries in 'near singular' configurations. This amplified 316 the forces experienced by the legs thereby creating a highly sensitive force sensor for specific load 
components. The prototypes developed in $[69,70]$ had heightened sensitivity to 3DOF-B loads and

318 the three moments respectively. Both designs employed flexural hinges for the leg joints and ring 319 structures instrumented with ERSGs on each leg. Seibold et al. [71] presented a small-scale sensor as 320 part of an articulated grasping instrument for minimally invasive robotic surgery applications. This 321 design used ERSGs and flexural joints and was sufficiently small to fit within a $10 \mathrm{~mm}$ diameter 322 sphere. Luo et al. [72] presented another small-scale design for use in robotic fingers. The sensor legs 323 were created from small brazen pipes ending in ball joints, created from rod end bearing and knuckle 324 joints. By having two legs meet at each ball joint, only six joints are required in this design. Yao et 325 al. [73] proposed the use of a pre-stress to improve the performance of mechanical spherical joints within the structure. An adjustable seventh leg spanning between the platform and base along the sensor centreline was used to induce a compressive force in the six platform legs. This prevented the 328 development of tension in the legs towards mitigating errors arising from non-linearity and 329 mechanical hysteresis in the joints.

330 Dwarakanath and Venkatesh [74] presented an alternative 'joint-less' design to overcome the 331 limitations of conventional mechanical and flexural joints. The design involved legs with conical ends 332 which rest in a spherical indentation on both the platform and base. The legs were secured in place 333 by a compressive pre-load using deadweight. Figure 19 shows the design proposed by Müller et al. 334 [75] using free-spanning, pre-tensioned FBGs as structures legs. This approach relies on having a 335 separate central cylinder structure to support the platform. The fibre was glued at support locations 336 on the base and platform after pre-tensioning and strain is induced in the FBGs by the relative change 337 in distance between these fixation points. A similar design was also presented by Kim and Lee [76]. 338 The sensors described in $[75,76]$ did not consider temperature compensation despite the experimental 339 results in [76] confirming the sensor outputs to be temperature dependent. Another FBG-based design 340 was proposed by Haslinger et al. [77], in which each leg is formed from a steel capillary with an 341 optical fibre containing an FBG bonded into the centre. The legs are bonded to top and bottom plates 
342 with structural epoxy, forming a relatively rigid joint. The effect of any bending of the legs is limited 343 by the FBGs being mounted within the centre of the capillaries and therefore on the neutral axis. 344 Temperature compensation is achieved in this design using an additional strain free FBG, mounted 345 in a steel capillary bonded to the baseplate.

\section{DISCUSSION AND CONCLUSIONS}

347 This paper has described a comprehensive review of multi-axis force sensors documented in the 348 literature over the past seven decades. The review first considered strain sensing technology used in 349 multi-axis force sensors. Electrical resistance strain gauges have for decades been the standard 350 mechanism for measuring strain induced on the sensor structure. Despite their ubiquity, these sensors 351 have inherent limitations that make their usage challenging, or indeed impractical, in many 352 applications. Specifically, the advantages fibre Bragg gratings offer include: (a) immunity to 353 electromagnetic interference, (b) reduced size and weight, (c) superior strain resolution, (d) 354 environmental ruggedness and (e) optical multiplexing. Although semiconductor strain gauges and 355 capacitive sensing have featured in the literature, they are primarily used in exceptional circumstances 356 such as in miniature force sensors.

357 The review of the elastic host structures highlighted the large variability of designs that have been 358 developed, perhaps understandably given the wide range of applications covered by this review. 359 Designs were broadly grouped as: (a) three DOF cross-beams, (b) six DOF cross-beams, (c) column360 type sensor, (d) column-beam sensors and (e) Stewart platform sensors. Cross-beam sensors appear 361 to have had much success as multi-axis force sensors in a range of configurations and applications. 362 Designs employing flexible-joints and features to concentrate strain have been shown to improve the 363 sensitivity and minimise coupling error of the sensor outputs. The main disadvantage associated with 364 these sensors is the considerable flexibility in the vertical direction as deformations are primarily in 365 bending. Column-type sensors are desirable due to their simple structure (and low fabrication costs), 
and the high stiffness in the vertical direction. However, accurate measurement of the applied forces

367 requires sensing of a complex strain field induced on the sensor host structure. To achieve a high 368 degree of accuracy, sensing elements are required to be placed at exact locations and orientations. 369 Although Stewart platforms have been shown to be effective, the literature has highlighted many issues associated with the development of the complex structure in conjunction with flexible joints.

Based on this review, there appears to be a concerted effort to develop force sensors employing FBG strain sensing. While the use of fibre optics in force sensors offers opportunities to re-visit simplified 373 host structures, temperature compensation remains one of the major obstacles. The relatively high 374 cost of optical analysers has also slowed its adoption into broad industrial sectors. Rapid 375 advancements in 3D printing also present exciting opportunities for the development of more 376 rigorous, complex host structures that were once considered either impractical or undesirable (due to 377 fabrication costs).

\section{ACKNOWLEDGEMENT}

379 This project was supported by the Royal Academy of Engineering under the Research Fellowship 380 Scheme.

\section{REFERENCES}

382 [1] N. Berme, P. Lawes, S. Solomonidis, J.P. Paul, A Shorter Pylon Transducer for Measurement 383 of Prosthetic Forces and Moments during Amputee Gait, Eng. Med. 4 (1975) 6-8. 384 https://doi.org/10.1243/EMED_JOUR_1975_004_032_02.

385 [2] B.W. Byrne, G.T. Houlsby, Investigating 6 degree-of-freedom loading on shallow 386 foundations, in: Proceedings of the First International Symposium of Frontiers in Offshore 387 Geotechnics, CRC Press, Perth, Australia, 2005: pp. 477-482. 388 https://doi.org/10.1201/NOE0415390637. 
389 [3] L.-P. Chao, C.-Y. Yin, The six-component force sensor for measuring the loading of the feet 390 in locomotion, Mater. Des. 20 (1999) 237-244. https://doi.org/10.1016/S0261-3069(99)00009-6.

391 [4] K.O. Hill, G. Meltz, Fiber Bragg grating technology fundamentals and overview, J. Lightwave 392 Technol. 15 (1997) 1263-1276. https://doi.org/10.1049/el:19910971.

393 [5] A. Othonos, Fiber Bragg gratings, Rev. Sci. Instrum. 68 (1997) 4309-4341. 394 https://doi.org/10.1063/1.1148392.

395 [6] S. Magne, S. Rougeault, M. Vilela, P. Ferdinand, State-of-strain evaluation with fiber Bragg 396 grating rosettes: application to discrimination between strain and temperature effects in fiber sensors, 397 Appl. Opt. 36 (1997) 9437-9447. https://doi.org/10.1364/AO.36.009437.

398 [7] A.D. Kersey, T.A. Berkoff, W.W. Morey, Fiber-optic Bragg grating strain sensor with drift399 compensated high-resolution interferometric wavelength-shift detection, Opt. Lett. 18 (1993) $72-74$. 400 https://doi.org/10.1364/OL.18.000072.

401 [8] M.G. Xu, J.-L. Archambault, L. Reekie, J.P. Dakin, Discrimination between strain and 402 temperature effects using dual-wavelength fibre grating sensors, Electron. Lett. 30 (1994) 1085-1087. 403 https://doi.org/10.1049/el:19940746.

404 [9] S.W. James, M.L. Dockney, R.P. Tatam, Simultaneous independent temperature and strain 405 measurement using in-fibre Bragg grating sensors, Electron. Lett. 32 (1996) 1133-1134. 406 https://doi.org/10.1049/el:19960732.

407 [10] M. Song, S.B. Lee, S.S. Choi, B. Lee, Interferometric temperature-insensitive strain 408 measurement with use of different-diameter fiber Bragg gratings, in: CLEO '97 - Summaries of 409 Papers Presented at the Conference on Lasers and Electro-Optics, IEEE, Baltimore, Maryland, USA, 410 1997: p. 419. https://doi.org/10.1109/CLEO.1997.603358. 
411 [11] H.J. Patrick, G.M. Williams, A.D. Kersey, J.R. Pedrazzani, A.M. Vengsarkar, Hybrid Fiber 412 Bragg Grating/Long Period Fiber Grating Sensor for Strain/Temperature Discrimination, IEEE 413 Photon. Technol. Lett. 8 (1996) 1223-1225. https://doi.org/10.1109/68.531843.

414 [12] S.E. Kanellopoulos, V.A. Handerek, A.J. Rogers, Simultaneous strain and temperature 415 sensing with photogenerated in-fiber gratings, Opt. Lett. 20 (1995) 333-335. 416 https://doi.org/10.1364/OL.20.000333.

417 [13] B.-O. Guan, H.-Y. Tam, X.-M. Tao, X.-Y. Dong, Simultaneous strain and temperature 418 measurement using a superstructure fiber Bragg grating, IEEE Photon. Technol. Lett. 12 (2000) 675419 677. https://doi.org/10.1109/68.849081.

420 [14] A. Fernandez Fernandez, F. Berghmans, B. Brichard, P. Mégret, M. Decréton, M. Blondel, 421 A. Delchambre, Multi-component force sensor based on multiplexed fibre Bragg grating strain 422 sensors, Meas. Sci. Technol. 12 (2001) 810-813. https://doi.org/10.1088/0957-0233/12/7/310.

423 [15] D.A.M. van der Laag, Design and Calibration of a Multi-Axial Load Cell for Quasi-Static and 424 Dynamic Testing, MSc Thesis, Delft University of Technology, 2016.

425 [16] M.G. Xu, J.-L. Archambault, L. Reekie, J.P. Dakin, Thermally-compensated bending gauge 426 using surface-mounted fibre gratings, Int. J. Optoelectron. 9 (1994) 281-283.

427 [17] H.-P. Phan, D.V. Dao, K. Nakamura, S. Dimitrijev, N.-T. Nguyen, The Piezoresistive Effect 428 of SiC for MEMS Sensors at High Temperatures: A Review, J. Microelectromech. Syst. 24 (2015) 429 1663-1677. https://doi.org/10.1109/JMEMS.2015.2470132.

430 [18] E.O. Doebelin, Measurement Systems: Application and Design, 4th ed., McGraw-Hill, New 431 York, 1990.

432 [19] Y. Kanda, Piezoresistance effect of silicon, Sens. Actuator A Phys. 28 (1991) 83-91. 433 https://doi.org/10.1016/0924-4247(91)85017-I. 
434 [20] W.P. Mason, R.N. Thurston, Use of Piezoresistive Materials in the Measurement of 435 Displacement, Force, and Torque, J. Acoust. Soc. Am. 29 (1957) 1096-1101. 436 https://doi.org/10.1121/1.1908710.

437 [21] P. Puangmali, K. Althoefer, L.D. Seneviratne, D. Murphy, P. Dasgupta, State-of-the-Art in 438 Force and Tactile Sensing for Minimally Invasive Surgery, IEEE Sens. J. 8 (2008) 371-381. 439 https://doi.org/10.1109/JSEN.2008.917481.

440 [22] A.L. Trejos, R.V. Patel, M.D. Naish, Force sensing and its application in minimally invasive 441 surgery and therapy: a survey, Proc. Inst. Mech. Eng. C. 224 (2010) 1435-1454. 442 https://doi.org/10.1243/09544062JMES1917.

443 [23] P. Valdastri, S. Roccella, L. Beccai, E. Cattin, A. Menciassi, M.C. Carrozza, P. Dario, 444 Characterization of a novel hybrid silicon three-axial force sensor, Sens. Actuator A Phys. 123-124 445 (2005) 249-257. https://doi.org/10.1016/j.sna.2005.01.006.

446 [24] M. Fontana, S. Marcheschi, F. Salsedo, M. Bergamasco, A Three-Axis Force Sensor for Dual 447 Finger Haptic Interfaces, Sensors. 12 (2012) 13598-13616. https://doi.org/10.3390/s121013598.

448 [25] R. Bekhti, V. Duchaine, P. Cardou, Miniature capacitive three-axis force sensor, in: 2014 449 IEEE/RSJ International Conference on Intelligent Robots and Systems, IEEE, Chicago, Illinois, USA, 450 2014: pp. 3939-3946. https://doi.org/10.1109/IROS.2014.6943116.

451 [26] L. Xiong, G. Jiang, Y. Guo, H. Liu, A Three-Dimensional Fiber Bragg Grating Force Sensor 452 for Robot, IEEE Sens. J. 18 (2018) 3632-3639. https://doi.org/10.1109/JSEN.2018.2812820.

453 [27] G.-S. Kim, D.-I. Kang, S.-H. Rhee, K.-W. Um, Design and fabrication of a three-component 454 force/moment sensor using plate-beams, Meas. Sci. Technol. 10 (1999) 295-301. 455 https://doi.org/10.1088/0957-0233/10/4/005. 
[28] D.M. Gorinevsky, A.M. Formalsky, A.Y. Schneider, Force Control of Robotic Systems, 4th 457 ed., CRC Press, Boca Raton, 1997.

458 [29] S.A. Liu, H.L. Tzo, A novel six-component force sensor of good measurement isotropy and 459 sensitivities, Sens. Actuator A Phys. 100 (2002) 223-230. https://doi.org/10.1016/S0924$460 \quad 4247(02) 00135-8$.

461 [30] M.-K. Kang, S. Lee, J.-H. Kim, Shape optimization of a mechanically decoupled six-axis 462 force/torque sensor, Sens. Actuator A $\quad$ Phys. $209 \quad$ (2014) 41-51. 463 https://doi.org/10.1016/j.sna.2014.01.001.

464 [31] D. Kim, C.H. Lee, B.C. Kim, D.H. Lee, H.S. Lee, C.T. Nguyen, U.K. Kim, T.D. Nguyen, H. 465 Moon, J.C. Koo, J.-D. Nam, H.R. Choi, Six-axis capacitive force/torque sensor based on dielectric 466 elastomer, in: Proceedings of SPIE 8687, Electroactive Polymer Actuators and Devices (EAPAD) 467 2013, SPIE, San Diego, California, USA, 2013: pp. 1-9. https://doi.org/10.1117/12.2009970.

468 [32] G. Palli, L. Moriello, U. Scarcia, C. Melchiorri, Development of an optoelectronic 6-axis 469 force/torque sensor for robotic applications, Sens. Actuator A Phys. 220 (2014) 333-346. 470 https://doi.org/10.1016/j.sna.2014.09.023.

471 [33] G. Lin, H. Pang, W. Zhang, D. Wang, L. Feng, A self-decoupled three-axis force sensor for 472 measuring the wheel force, Proc. Inst. Mech. Eng. D. 228 (2014) 319-334. 473 https://doi.org/10.1177/0954407013508278.

474 [34] L. Feng, G. Lin, Z. W, H. Pang, T. Wang, Design and optimization of a self-decoupled six475 axis wheel force transducer for a heavy truck, Proc. Inst. Mech. Eng. D. 229 (2015) 1585-1610. 476 https://doi.org/10.1177/0954407014566439.

477 [35] V.D. Scheinman, Design of a computer controlled manipulator, MS Thesis, Stanford 478 University, 1969. 
479 [36] B. Shimano, B. Roth, On Force Sensing Information and Its Use in Controlling Manipulators, 480 in: IFAC Proceedings Volumes, Tokyo, Japan, 1977: pp. 119-126. https://doi.org/10.1016/S1474$481 \quad 6670(17) 66591-1$.

482 [37] H. Van Brussel, H. Belien, H. Thielemans, Force sensing for advanced robot control, 483 Robotics. 2 (1986) 139-148. https://doi.org/10.1016/0167-8493(86)90050-1.

484 [38] L.-P. Chao, K.-T. Chen, Shape optimal design and force sensitivity evaluation of six-axis 485 force sensors, Sens. Actuator A Phys. 63 (1997) 105-112. https://doi.org/10.1016/S0924$486 \quad 4247(97) 01534-3$.

487 [39] D.V. Dao, T. Toriyama, J. Wells, S. Sugiyama, Six-degree of freedom micro force-moment 488 sensor for application in geophysics, in: Technical Digest. MEMS 2002 IEEE International 489 Conference. Fifteenth IEEE International Conference on Micro Electro Mechanical Systems (Cat. 490 No.02CH37266), Las Vegas, Nevada, USA, 2002: pp. 312-315. 491 https://doi.org/10.1109/MEMSYS.2002.984265.

492 [40] W. Shi, S.D. Hall, A novel six-axis force sensor for measuring the loading of the racing tyre 493 on track, in: Proceedings of 1st International Conference on Sensing Technology (ICST2005), 494 Palmerston North, New Zealand, 2005: pp. 408-413.

495 [41] J. Ma, A. Song, Fast Estimation of Strains for Cross-Beams Six-Axis Force/Torque Sensors 496 by Mechanical Modeling, Sensors. 13 (2013) 6669-6686. https://doi.org/10.3390/s130506669.

497 [42] G.-S. Kim, Design of a six-axis wrist force/moment sensor using FEM and its fabrication for 498 an intelligent robot, Sens. Actuator A Phys. $133 \quad$ (2007) 27-34. 499 https://doi.org/10.1016/j.sna.2006.03.038. 
500 [43] G.-S. Kim, H.-J. Shin, J. Yoon, Development of 6-axis force/moment sensor for a humanoid 501 robot's intelligent foot, Sens. Actuator A Phys. $141 \quad$ (2008) 276-281. 502 https://doi.org/10.1016/j.sna.2007.08.011.

503 [44] G. Mastinu, M. Gobbi, G. Previati, A New Six-axis Load Cell. Part I: Design, Exp. Mech. 51 504 (2011) 373-388. https://doi.org/10.1007/s11340-010-9355-1.

505 [45] M. Gobbi, G. Previati, P. Guarneri, G. Mastinu, A New Six-Axis Load Cell. Part II: Error 506 Analysis, Construction and Experimental Assessment of Performances, Exp. Mech. 51 (2011) 389507 399. https://doi.org/10.1007/s11340-010-9350-6.

508 [46] Y. Sun, Y. Liu, M. Jin, H. Liu, Design and optimization of a novel six-axis force/torque sensor 509 with good isotropy and high sensitivity, in: 2013 IEEE International Conference on Robotics and 510 Biomimetics (ROBIO), IEEE, Shenzen, China, 2013: pp. 631-638. 511 https://doi.org/10.1109/ROBIO.2013.6739530.

512 [47] A. Kazerooni, H. Akbari, Proposing an index for qualitative comparison of six-axis 513 force/torque sensors and optimization of Maltese cross geometry to reduce cross-coupling error, 514 Modares Mech. Eng. 17 (2017) 153-164.

515 [48] L. Schickl, K. Dorer, M. Wülker, U. Hochberg, Development of a Six-Axis Force and Torque 516 Sensor for the Humanoid Robot Sweaty 2.0, in: Proceedings of the 11th Workshop on Humanoid 517 Soccer Robots, 2016 IEEE-RAS International Conference on Humanoid Robots, Cancun, Mexico, 5182016.

519 [49] D. Chen, A. Song, A. Li, Design and Calibration of a Six-axis Force/torque Sensor with Large 520 Measurement Range Used for the Space Manipulator, Procedia Eng. 99 (2015) 1164-1170. 521 https://doi.org/10.1016/j.proeng.2014.12.699. 
522 [50] J. Huang, C.Y. Wong, D.T. Pham, Y. Wang, C. Ji, S. Su, W. Xu, Q. Liu, Z. Zhou, Design of 523 a Novel Six-Axis Force/Torque Sensor based on Optical Fibre Sensing for Robotic Applications, in:

524 Proceedings of the 15th International Conference on Informatics in Control, Automation and Robotics 525 (ICINCO 2018), Porto, Portugal, 2018: pp. 517-524. https://doi.org/10.5220/0006911705170524.

526 [51] Y. Wang, G. Zuo, X. Chen, L. Liu, Strain Analysis of Six-Axis Force/Torque Sensors Based 527 on Analytical Method, IEEE Sens. J. $17 \quad$ (2017) 4394-4404. 528 https://doi.org/10.1109/JSEN.2017.2703160.

529 [52] G.-S. Kim, D.-I. Kang, S.-H. Rhee, Design and fabrication of a six-component force/moment 530 sensor, Sens. Actuator A Phys. 77 (1999) 209-220. https://doi.org/10.1016/S0924-4247(99)00208-3. 531 [53] C. Yuan, L.-P. Luo, Q. Yuan, J. Wu, R.J. Yan, H. Kim, K.-S. Shin, C.-S. Han, Development 532 and evaluation of a compact 6-axis force/moment sensor with a serial structure for the humanoid 533 robot foot, Measurement. 70 (2015) 110-122. https://doi.org/10.1016/j.measurement.2015.03.027.

534 [54] B. Wu, P. Cai, Decoupling Analysis of a Sliding Structure Six-axis Force/Torque Sensor, 535 Meas. Sci. Rev. 13 (2013) 187-193. https://doi.org/10.2478/msr-2013-0028.

536 [55] R. Bekhti, Geometrical, mechanical and transduction techniques for designing multi-axis 537 force-torque sensors for robotic applications, $\mathrm{PhD}$ Thesis, École de technologie supérieure, Université 538 du Québec, 2015.

539 [56] Cunningham D.M., G.W. Brown, Two devices for measuring the forces acting on the human 540 body during walking, Proc. Soc. Exp. Stress Anal. 9 (1952) 75-90.

541 [57] J.P. Paul, Forces at the human hip joint, PhD Thesis, University of Glasgow, 1967.

542 [58] M.A. Stroud, The behaviour of sand at low stress levels in simple shear apparatus, $\mathrm{PhD}$ Thesis, 543 University of Cambridge, 1971. 
544 [59] P.L. Bransby, Cambridge contact stress transducers, Department of Engineering, University 545 of Cambridge, 1972.

546 [60] W. Huang, H. Jiang, H. Zhou, Mechanical analysis of a novel six-degree-of-freedom wrist 547 force sensor, Sens. Actuator A Phys. 35 (1993) 203-208. https://doi.org/10.1016/0924$548 \quad 4247(93) 80153-8$.

549 [61] D. Stewart, A Platform with Six Degrees of Freedom, Proc. Inst. Mech. Eng. 180 (1965) 371550 386. https://doi.org/10.1243/PIME_PROC_1965_180_029_02.

551 [62] C.-G. Kang, Closed-form force sensing of a 6-axis force transducer based on the Stewart 552 platform, Sens. Actuator A Phys. 90 (2001) 31-37. https://doi.org/10.1016/S0924-4247(00)00564-1. 553 [63] A. Romiti, M. Sorli, Force and moment measurement on a robotic assembly hand, Sens. 554 Actuator A Phys. 32 (1992) 531-538. https://doi.org/10.1016/0924-4247(92)80039-6.

555 [64] M. Sorli, N. Zhmud́, Investigation of force and moment measurement system for a robotic 556 assembly hand, Sens. Actuator A Phys. 37-38 (1993) 651-657. https://doi.org/10.1016/0924557 4247(93)80111-S.

558 [65] C. Ferraresi, S. Pastorelli, M. Sorli, N. Zhmud', State and dynamic behavior of a high stiffness 559 stewart platform-based force/torque sensor, J. Robot. Syst. 12 (1995) 883-893. 560 https://doi.org/10.1002/rob.4620121211.

561 [66] J.S. Dai, D.R. Kerr, A six-component contact force measurement device based on the Stewart 562 platform, Proc. Inst. Mech. Eng. C. 214 (2000) 687-697. https://doi.org/10.1243/0954406001523696.

563 [67] T.A. Dwarakanath, B. Dasgupta, T.S. Mruthyunjaya, Design and development of a Stewart 564 platform based force-torque sensor, Mechatronics. $11 \quad$ (2001) 793-809. 565 https://doi.org/10.1016/S0957-4158(00)00048-9. 
566 [68] J. Zhenlin, G. Feng, Z. Xiaohui, Design and analysis of a novel isotropic six-component 567 force/torque sensor, Sens. Actuator A Phys. 109 (2003) 17-20. https://doi.org/10.1016/S0924568 4247(03)00299-1.

569 [69] R. Ranganath, P.S. Nair, T.S. Mruthyunjaya, A. Ghosal, A force-torque sensor based on a 570 Stewart Platform in a near-singular configuration, Mech. Mach. Theory. 39 (2004) 971-998. 571 https://doi.org/10.1016/j.mechmachtheory.2004.04.005.

572 [70] S. Bhavikatti, R. Ranganath, A. Ghosal, A near-singular, flexure jointed, moment sensitive 573 Stewart platform based force-torque sensor, in: Proceedings of the 13th National Conference on 574 Machines and Mechanisms, Bangalore, India, 2007: pp. 67-74.

575 [71] U. Seibold, B. Kubler, G. Hirzinger, Prototype of Instrument for Minimally Invasive Surgery 576 with 6-Axis Force Sensing Capability, in: Proceedings of the 2005 IEEE International Conference on 577 Robotics and Automation, IEEE, Barcelona, Spain, 2005: pp. 496-501. 578 https://doi.org/10.1109/ROBOT.2005.1570167.

579 [72] M. Luo, E. Shimizu, F. Zhang, M. Ito, Development of a Stewart Platform-based 6-axis Force 580 Sensor for Robot Fingers, in: ICCAS2005, Gyeonggi-do, South Korea, 2005.

581 [73] J. Yao, Y. Hou, L. Lu, Y. Zhao, Analysis of a Pre-stressed Six-component Force/Torque 582 Sensor Based on Stewart Platform, in: Proceedings of the 2006 IEEE International Conference on 583 Robotics and Biomimetics, IEEE, Kunming, China, 2006: pp. 346-350. 584 https://doi.org/10.1109/ROBIO.2006.340200.

585 [74] T.A. Dwarakanath, D. Venkatesh, Simply supported, 'Joint less' parallel mechanism based 586 force-torque sensor, Mechatronics. 16 (2006) $565-575$.

587 https://doi.org/10.1016/j.mechatronics.2006.03.013. 
588 [75] M.S. Müller, L. Hoffmann, T.C. Buck, A.W. Koch, Fiber Bragg Grating-Based Force-Torque 589 Sensor with Six Degrees of Freedom, Int. J. Optomechatronics. 3 (2009) 201-214. 590 https://doi.org/10.1080/15599610903144146.

591 [76] G.-S. Kim, H.-D. Lee, Development of a six-axis force/moment sensor and its control system 592 for an intelligent robot's gripper, Meas. Sci. Technol. 14 (2003) 1265-1274. 593 https://doi.org/10.1088/0957-0233/14/8/311.

594 [77] R. Haslinger, P. Leyendecker, U. Seibold, A Fiberoptic Force-Torque-Sensor for Minimally 595 Invasive Robotic Surgery, in: 2013 IEEE International Conference on Robotics and Automation, 596 IEEE, Karlsruhe, Germany, 2013: pp. 4390-4395. https://doi.org/10.1109/ICRA.2013.6631199.

597 [78] R. Richardson, M. Brown, B. Bhakta, M.C. Levesley, Design and control of a three degree of 598 freedom pneumatic physiotherapy robot, Robotica. 21 (2003) 589-604.

599 [79] J.H. Kim, D.I. Kang, H.H. Shin, Y.K. Park, Design and analysis of a column type multi600 component force/moment sensor, Measurement. 33 (2003) 213-219. 
Table 1 Summary of three DOF cross-beam force sensors documented in the literature

\begin{tabular}{|c|c|c|c|c|c|c|c|}
\hline Reference & $\begin{array}{l}\text { 3DOF } \\
\text { type }\end{array}$ & $\begin{array}{l}\text { Strain } \\
\text { sensing } \\
\text { (number of } \\
\text { sensors) }\end{array}$ & Construction comments & Sensor size & $\begin{array}{l}\text { Measurement } \\
\text { range }^{\text {a }}\end{array}$ & Measurement particulars ${ }^{b}$ & Application $^{c}$ \\
\hline $\begin{array}{l}\text { Bekhti et al. } \\
{[25]}\end{array}$ & A & $\begin{array}{l}\text { Capacitance } \\
\text { (4) }\end{array}$ & $\begin{array}{l}\text { Plastic structure, pairs of } \\
\text { parallel beams in cross }\end{array}$ & $20 \mathrm{~mm} \times 20 \mathrm{~mm} \times 14 \mathrm{~mm}$ & $\begin{array}{l}F_{\mathrm{x}}=F_{\mathrm{y}}=60 \mathrm{~N}, F_{\mathrm{z}} \\
=100 \mathrm{~N}\end{array}$ & R: $0.05 \%$ & Robot control \\
\hline $\begin{array}{l}\text { Fernandez } \\
\text { Fernandez et } \\
\text { al. [14] }\end{array}$ & $\mathrm{C}$ & FBG (8) & $\begin{array}{l}\text { Rigid joints, square } \\
\text { cross-section beams }\end{array}$ & $\begin{array}{l}\text { Beam lengths }=50 \mathrm{~mm} \text {, Beam } \\
\text { cross section }=4 \mathrm{~mm} \times 4 \mathrm{~mm} \text {, } \\
\text { Central platform radius }=25 \mathrm{~mm}\end{array}$ & $\begin{array}{l}F_{\mathrm{z}}=475 \mathrm{~N}, M_{\mathrm{x}}= \\
M_{\mathrm{y}}=6.5 \mathrm{Nm}\end{array}$ & - & $\begin{array}{l}\text { Robot control (in } \\
\text { EM noisy } \\
\text { environments) }\end{array}$ \\
\hline $\begin{array}{l}\text { Fontana et } \\
\text { al. [24] }\end{array}$ & A & ERSG (16) & $\begin{array}{l}\text { Rigid joints, vertically } \\
\text { compliant beams }\end{array}$ & $\begin{array}{l}\text { Beam lengths }=7.4 \mathrm{~mm}, \text { Beam } \\
\text { cross section }=3 \mathrm{~mm} \times 0.4 \mathrm{~mm}\end{array}$ & $\begin{array}{l}F_{\mathrm{x}}=F_{\mathrm{y}}=F_{\mathrm{z}}= \pm 5 \\
\mathrm{~N}\end{array}$ & $\begin{array}{l}\text { R: } 0.04 \% \\
\text { CE: } 0.1 \% \\
\text { NE: } 0.06 \% \\
\text { HE: } 0.21 \%\end{array}$ & $\begin{array}{l}\text { Dual-finger haptic } \\
\text { interface }\end{array}$ \\
\hline $\begin{array}{l}\text { Kim et al. } \\
{[27]}\end{array}$ & $\mathrm{B}$ & ERSG (40) & $\begin{array}{l}\text { Laterally flexible plate } \\
\text { beams in both cross- } \\
\text { members and frame, both } \\
\text { instrumented }\end{array}$ & $\begin{array}{l}\text { Beam lengths }=17 \mathrm{~mm} \text {, Beam } \\
\text { cross section }=14 \mathrm{~mm} \times 1.8 \mathrm{~mm}\end{array}$ & $\begin{array}{l}F_{\mathrm{x}}=F_{\mathrm{y}}=100 \mathrm{~N} \\
M_{\mathrm{z}}=2 \mathrm{Nm}\end{array}$ & CE: $0.01-1.7 \%$ & $\begin{array}{l}\text { General sensor } \\
\text { development }\end{array}$ \\
\hline $\begin{array}{l}\text { Lin et al. } \\
{[33]}\end{array}$ & $\mathrm{B}$ & ERSG (16) & $\begin{array}{l}\text { Eight-spoked design with } \\
\text { rigid joints }\end{array}$ & $\begin{array}{l}\text { Diameter }=290 \mathrm{~mm}, \text { Thickness }= \\
10 \mathrm{~mm}\end{array}$ & $\begin{array}{l}F_{\mathrm{x}}=F_{\mathrm{y}}=14 \mathrm{kN} \\
M_{\mathrm{z}}=3000 \mathrm{Nm}\end{array}$ & $\begin{array}{l}\text { HE: } 0.9-1.1 \% \\
\text { NE: } 0.6-0.9 \% \\
\text { RE: } 0.5 \%\end{array}$ & $\begin{array}{l}\text { Wheel force } \\
\text { measurement }\end{array}$ \\
\hline $\begin{array}{l}\text { Richardson } \\
\text { et al. [78] }\end{array}$ & A & ERSG (8) & $\begin{array}{l}\text { Rigid joints, vertically } \\
\text { compliant beams }\end{array}$ & $\begin{array}{l}70 \mathrm{~mm} \times 70 \mathrm{~mm} \text { (overall). Beam } \\
\text { cross sections }=5 \mathrm{~mm} \times 2 \mathrm{~mm}\end{array}$ & $\begin{array}{l}F_{\mathrm{x}}=F_{\mathrm{y}}=F_{\mathrm{z}}= \pm \\
20 \mathrm{~N}\end{array}$ & - & $\begin{array}{l}\text { Control of } \\
\text { pneumatic } \\
\text { physiotherapy robot }\end{array}$ \\
\hline $\begin{array}{l}\text { Valdastri et } \\
\text { al. [23] }\end{array}$ & A & $\begin{array}{l}\text { Piezoresistiv } \\
\text { e (4) }\end{array}$ & $\begin{array}{l}\text { Silicon structure, } \\
\text { piezoresistors obtained } \\
\text { by ion implantation }\end{array}$ & $2.3 \mathrm{~mm} \times 2.3 \mathrm{~mm} \times 1.3 \mathrm{~mm}$ & $\begin{array}{l}F_{\mathrm{x}}=F_{\mathrm{y}}=0-0.4 \mathrm{~N} \\
F_{\mathrm{z}}=0-2.5 \mathrm{~N}\end{array}$ & $\begin{array}{l}\mathrm{S}: 0.0254-0.026 \mathrm{~N}^{-1}\left(F_{\mathrm{x}}, F_{\mathrm{y}} \text {, }\right. \\
\left.F_{\mathrm{z}}\right) .\end{array}$ & $\begin{array}{l}\text { Interface force } \\
\text { measurement for } \\
\text { prosthetic }\end{array}$ \\
\hline
\end{tabular}


NE: $0.28 \%\left(F_{\mathrm{z}}\right)-2.5 \%\left(F_{\mathrm{x}}\right.$

$\left.F_{\mathrm{y}}\right)$

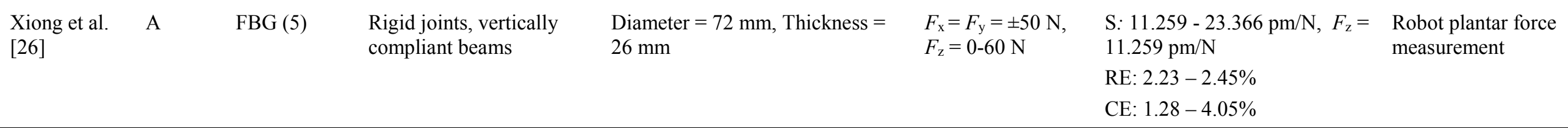

${ }^{\mathrm{a}}$ Measurement ranges as reported by the respective authors or deduced from calibration plots

${ }^{\mathrm{b}}$ Measurement particulars as reported by the respective authors; $\mathrm{R}=$ resolution, $\mathrm{S}=$ sensitivity, $\mathrm{NE}=$ nonlinearity error, $\mathrm{HE}=$ hysteresis error, $\mathrm{RE}=$ repeatability error, $\mathrm{CE}=$ coupling error

'Studies that do not refer to a specific application for the development of the respective sensor are listed here as 'general sensor development' 
Table 2 Summary of six DOF cross-beam force sensors documented in the literature

\begin{tabular}{|c|c|c|c|c|c|c|}
\hline Reference & $\begin{array}{l}\text { Strain sensing } \\
\text { (number of } \\
\text { sensors) }\end{array}$ & Construction comments & Sensor size & Measurement range $^{a}$ & $\begin{array}{l}\text { Measurement } \\
\text { particulars }^{b}\end{array}$ & Application $^{\mathrm{c}}$ \\
\hline $\begin{array}{l}\text { Chao and } \\
\text { Chen [38] }\end{array}$ & $\begin{array}{l}\text { ERSG }(16,24, \\
32,48)\end{array}$ & Ball-bearing frame-beam joints & - & $\begin{array}{l}F_{\mathrm{x}}=F_{\mathrm{y}}=392 \mathrm{~N}, F_{\mathrm{z}}= \\
784 \mathrm{~N}, M_{\mathrm{x}}=M_{\mathrm{y}}=20 \\
\mathrm{Nm}, M_{\mathrm{z}}=29 \mathrm{Nm}\end{array}$ & - & $\begin{array}{l}\text { Wrist force sensor } \\
\text { for robotic arm } \\
\text { control }\end{array}$ \\
\hline $\begin{array}{l}\text { Chao and Yin } \\
\text { [3] }\end{array}$ & ERSG (32) & Rigid-jointed & - & $\begin{array}{l}F_{\mathrm{x}}=F_{\mathrm{y}}=600 \mathrm{~N}, F_{\mathrm{z}}=- \\
1200 \mathrm{~N}, M_{\mathrm{x}}=M_{\mathrm{y}}=3600 \\
\mathrm{Nmm}, M_{\mathrm{z}}=5400 \mathrm{Nmm}\end{array}$ & - & $\begin{array}{l}\text { Measuring reaction } \\
\text { loads on human feet } \\
\text { during locomotion }\end{array}$ \\
\hline $\begin{array}{l}\text { Chen et al. } \\
\text { [49] }\end{array}$ & ERSG (-) & Compliant edge beams & $\begin{array}{l}\text { Diameter }=370 \\
\text { mm }(\text { overall }) \\
\text { height }=146 \mathrm{~mm} \\
\text { (overall) }\end{array}$ & $\begin{array}{l}F_{\mathrm{x}}=F_{\mathrm{y}}=10000 \mathrm{~N}, F_{\mathrm{z}}= \\
12000 \mathrm{~N}, M_{\mathrm{x}}=M_{\mathrm{y}}= \\
2000 \mathrm{Nm}, M_{\mathrm{z}}=3000 \\
\mathrm{Nm}\end{array}$ & $\begin{array}{l}\mathrm{R}:<20 \mathrm{~N}\left(F_{\mathrm{x}}, F_{\mathrm{y}}, F_{\mathrm{z}}\right),<3 \\
\mathrm{~N}\left(M_{\mathrm{x}}, M_{\mathrm{y}}, M_{\mathrm{z}}\right) \\
\mathrm{CE}: 0.03-1.84 \%\end{array}$ & $\begin{array}{l}\text { Control of large } \\
\text { robotic manipulator } \\
\text { for space } \\
\text { applications }\end{array}$ \\
\hline Dao et al. [39] & SSGs (18) & $\begin{array}{l}\text { n-type micro silicon cross-beam with } \\
\text { piezoresistors formed on surface } \\
\text { through impurity diffusion }\end{array}$ & $\begin{array}{l}\text { Overall chip } \\
\text { dimensions }=3000 \\
\mu \mathrm{m} \times 3000 \mu \mathrm{m} \times \\
400 \mu \mathrm{m}\end{array}$ & $\begin{array}{l}F_{\mathrm{x}}=F_{\mathrm{y}}=F_{\mathrm{z}}=50 \mathrm{~N}, M_{\mathrm{x}} \\
=M_{\mathrm{y}}=M_{\mathrm{z}}=2 \times 10^{-4} \\
\mathrm{mN} \mu \mathrm{m}\end{array}$ & $\begin{array}{l}\text { S: } 0.11-1.15 \mathrm{mV} / \mathrm{mN}\left(F_{\mathrm{x}},\right. \\
\left.F_{\mathrm{y}}, F_{\mathrm{z}}\right), 3.4 \times 10^{-3}-4.6 \times 10^{-4} \\
\mathrm{mV} / \mathrm{mN} \mu \mathrm{m}\left(M_{\mathrm{x}}, M_{\mathrm{y}}, M_{\mathrm{z}}\right) \\
\mathrm{NE}: 0.5-2.5 \%\end{array}$ & $\begin{array}{l}\text { Measuring forces } \\
\text { acting on a particle at } \\
\text { the bed of a turbulent } \\
\text { channel flow }\end{array}$ \\
\hline Feng et al. [34] & ERSG (32) & Eight-spoke design with rigid joints & - & $\begin{array}{l}F_{\mathrm{x}}=F_{\mathrm{y}}=120 \mathrm{kN}, F_{\mathrm{z}}= \\
60 \mathrm{kN}, M_{\mathrm{x}}=M_{\mathrm{y}}=30 \\
\mathrm{kNm}, M_{\mathrm{z}}=60 \mathrm{kN} \mathrm{m}\end{array}$ & $\begin{array}{l}\mathrm{S}: 10.5-110 \mu / \mathrm{kN}\left(F_{\mathrm{x}}, F_{\mathrm{y}},\right. \\
\left.F_{\mathrm{z}}\right), 1.15-1.20 \mu / \mathrm{kNm}\left(M_{\mathrm{x}},\right. \\
\left.M_{\mathrm{y}}, M_{\mathrm{z}}\right) \\
\mathrm{NE}: 0.6-1.0 \% \\
\mathrm{HE}: 0.6-1.3 \% \\
\mathrm{RE}: 0.4-0.65 \%\end{array}$ & $\begin{array}{l}\text { Wheel force } \\
\text { transducer for a } \\
\text { heavy truck }\end{array}$ \\
\hline $\begin{array}{l}\text { Huang et al. } \\
{[50]}\end{array}$ & FBG (16) & $\begin{array}{l}\text { Square cross-section beams with } \\
\text { compliant plates at frame-beam } \\
\text { joints }\end{array}$ & - & - & - & $\begin{array}{l}\text { Robotic applications } \\
\text { in harsh industrial } \\
\text { environments }\end{array}$ \\
\hline $\begin{array}{l}\text { Kang et al. } \\
{[30] \text {; }}\end{array}$ & ERSG (24) & $\begin{array}{l}\text { Square cross-section beams with } \\
\text { compliant plates at frame-beam } \\
\text { joints }\end{array}$ & $\begin{array}{l}\text { Diameter }=92 \mathrm{~mm} \\
\text { (overall), height }= \\
37 \mathrm{~mm} \text { (overall) }\end{array}$ & $\begin{array}{l}F_{\mathrm{x}}=F_{\mathrm{y}}= \pm 400 \mathrm{~N}, F_{\mathrm{z}}= \pm \\
800 \mathrm{~N}, M_{\mathrm{x}}=M_{\mathrm{y}}=M_{\mathrm{z}}= \pm \\
40 \mathrm{Nm}\end{array}$ & CE: $0-3.2 \%$ & $\begin{array}{l}\text { General sensor } \\
\text { development }\end{array}$ \\
\hline
\end{tabular}




\section{Kim et al. [52]}

ERSG (56)

$\operatorname{Kim}[42]$

ERSG (24)

Kim et al. [43] ERSG (24)

Kim et al. [31] Capacitance

Ma and Song

[41]

Mastinu et al.

[44]; Gobbi et

al. [45]

Palli et al. [32] Optoelectronic

ERSG (24)

ERSG (12)

Loads applied to a reflective surface mounted on cross-beam frame

Compliant supports at frame-beam joints

Dual cross-beam (3DOF-B and 3DOF-C, created from plate beams) connected at the frame

Laterally compliant parallel-platebeams in the frame, square crosssection cross-beam members

Parallel-plate-beams in both crossbeam members and frame

Plastic cross-beam, grooves cut into beams to allow capacitive sensing

Square cross-section beams, with compliant members at the framebeam joint

Three-spoke design with 'spherical sliding joints'

Scheinman

SSG (16)

[35]

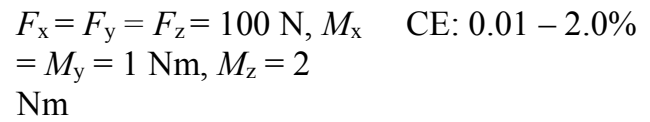

Diameter $=100$

$\mathrm{mm}$ (overall),

height $=31 \mathrm{~mm}$

(overall)

Overall

dimensions $=80$

$\mathrm{mm} \times 80 \mathrm{~mm} \times 19$

$\mathrm{mm}$

$F_{\mathrm{x}}=F_{\mathrm{y}}=F_{\mathrm{z}}=200 \mathrm{~N}, M_{\mathrm{x}}$

$=M_{\mathrm{y}}=2.5 \mathrm{Nm}, M_{\mathrm{z}}=5$

$\mathrm{Nm}$

$F_{\mathrm{x}}=F_{\mathrm{y}}=500 \mathrm{~N}, F_{\mathrm{z}}=$

$1000 \mathrm{~N}, M_{\mathrm{x}}=M_{\mathrm{y}}=18$

$\mathrm{Nm}, M_{\mathrm{z}}=8 \mathrm{Nm}$

Diameter $=67 \mathrm{~mm}$ (overall), height $=$ $30 \mathrm{~mm}$ (overall)

$F_{\mathrm{x}}=F_{\mathrm{y}}=F_{\mathrm{z}}=10 \mathrm{~N}, M_{\mathrm{x}}$

$=M_{\mathrm{y}}=M_{\mathrm{z}}=0.16 \mathrm{Nm}$

Overall

$F_{\mathrm{x}}=F_{\mathrm{y}}= \pm 100 \mathrm{~N}, F_{\mathrm{z}}=-$

dimensions $=96 \quad 100 \mathrm{~N}, M_{\mathrm{x}}=M_{\mathrm{y}}= \pm 10$

$\mathrm{mm} \times 96 \mathrm{~mm} \times 7.2 \quad \mathrm{Nm}, M_{\mathrm{z}}=12 \mathrm{Nm}$

$\mathrm{mm}$

Overall

$F_{\mathrm{x}}=F_{\mathrm{y}}=5 \mathrm{kN}, F_{\mathrm{z}}=10$

dimensions $=150 \quad \mathrm{kN}, M_{\mathrm{x}}=M_{\mathrm{y}}=M_{\mathrm{z}}=0.5$

$\mathrm{mm} \times 175 \mathrm{~mm} \times$

$100 \mathrm{~mm}$

Beam length $=$

$16.5 \mathrm{~mm}$, beam

cross section $=4.8$

$\mathrm{mm} \times 1.5 \mathrm{~mm}$

Diameter $=5.3 \mathrm{~cm}$ (overall), height $=$

$F_{\mathrm{x}}=F_{\mathrm{y}}=106 \mathrm{~N}, F_{\mathrm{z}}=$ $167 \mathrm{~N}, M_{\mathrm{x}}=M_{\mathrm{y}}=162$ $\mathrm{Ncm}, M_{\mathrm{z}}=300 \mathrm{Ncm}$
$\mathrm{R}: 5 \%\left(F_{\mathrm{x}}, F_{\mathrm{y}}, F_{\mathrm{z}}\right), 12.5 \%$ $\left(M_{\mathrm{x}}, M_{\mathrm{y}}, M_{\mathrm{z}}\right)$

NE: $4.7-12.1 \%$

General sensor development

Robot wrist force sensor

Humanoid intelligent robot's foot

Robotics applications

Robotics applications

CE: $<1.0 \%$ $\left(M_{\mathrm{x}}, M_{\mathrm{y}}, M_{\mathrm{z}}\right)$

Characterisation of vehicle suspension systems

Robotics applications

A: $1 \%$

Wrist force sensor in the 'Stanford Arm' robotic manipulator 


\begin{tabular}{|c|c|c|c|c|c|c|}
\hline $\begin{array}{l}\text { Schickl et al. } \\
{[48]}\end{array}$ & ERSG (16) & $\begin{array}{l}\text { Flexible members at frame-beam } \\
\text { joints }\end{array}$ & - & $\begin{array}{l}F_{\mathrm{x}}=F_{\mathrm{y}}=800 \mathrm{~N}, F_{\mathrm{z}}= \\
2100 \mathrm{~N}, M_{\mathrm{x}}=M_{\mathrm{y}}=M_{\mathrm{z}}= \\
50 \mathrm{Nm}\end{array}$ & - & $\begin{array}{l}\text { Humanoid robot feet } \\
\text { force measurement }\end{array}$ \\
\hline $\begin{array}{l}\text { Shi and Hall } \\
{[40]}\end{array}$ & ERSG (16) & $\begin{array}{l}\text { Square cross-section beams, } \\
\text { spherical plain bearings at frame- } \\
\text { beam joints }\end{array}$ & - & $\begin{array}{l}F_{\mathrm{x}}=-1000-500 \mathrm{~N}, F_{\mathrm{y}}- \\
500-1250 \mathrm{~N}, F_{\mathrm{z}}=-750 \\
-1000 \mathrm{~N}, M_{\mathrm{x}}=-150-50 \\
\mathrm{Nm}, M_{\mathrm{y}}=-125-50 \mathrm{Nm}\end{array}$ & $\begin{array}{l}\mathrm{R}: 0.21 \mu / \mathrm{kg}\left(F_{\mathrm{x}}, F_{\mathrm{y}}, F_{\mathrm{z}}\right) \\
1.16 \mu / \operatorname{kgm}\left(M_{\mathrm{x}}, M_{\mathrm{y}}, M_{\mathrm{z}}\right)\end{array}$ & Wheel force sensor \\
\hline Sun et al. [46] & ERSG (32) & $\begin{array}{l}\text { Double-bending-beam structures in } \\
\text { cross and frame members, both } \\
\text { instrumented }\end{array}$ & $\begin{array}{l}\text { Diameter }=224 \\
\text { mm }(\text { overall) } \\
\text { height }=117 \mathrm{~mm} \\
\text { (overall) }\end{array}$ & $\begin{array}{l}F_{\mathrm{x}}=F_{\mathrm{y}}=F_{\mathrm{z}}= \pm 500 \mathrm{~N} \\
M_{\mathrm{x}}=M_{\mathrm{y}}=M_{\mathrm{z}}= \pm 100 \\
\mathrm{Nm}\end{array}$ & CE: $1.24-6.47 \%$ & Robotics applications \\
\hline $\begin{array}{l}\text { Van Brussel et } \\
\text { al. [37] }\end{array}$ & ERSG (-) & Thin flexures at rim & - & $\begin{array}{l}F_{\mathrm{x}}=F_{\mathrm{y}}=F_{\mathrm{z}}=20 \mathrm{~N}, M_{\mathrm{x}} \\
=M_{\mathrm{y}}=M_{\mathrm{z}}=1 \mathrm{Nm}\end{array}$ & - & Robot control \\
\hline $\begin{array}{l}\text { Wu and Cai } \\
{[54]}\end{array}$ & ERSG (32) & $\begin{array}{l}\text { Dual cross-beam (3DOF-B and } \\
3 \text { DOF-C with double-hole } \\
\text { structures) sliding structure within } \\
\text { cylindrical shell }\end{array}$ & $\begin{array}{l}\text { Diameter }=52 \mathrm{~mm} \\
\text { (overall), height }= \\
28 \mathrm{~mm} \text { (overall) }\end{array}$ & $\begin{array}{l}F_{\mathrm{x}}=F_{\mathrm{y}}=F_{\mathrm{z}}=0-20 \mathrm{~N} \\
M_{\mathrm{x}}=M_{\mathrm{y}}=M_{\mathrm{z}}=0-800 \\
\mathrm{Nmm}\end{array}$ & $\begin{array}{l}\mathrm{S}: 4.2-5.4 \mathrm{mV} / \mathrm{N}\left(F_{\mathrm{x}}, F_{\mathrm{y}},\right. \\
\left.F_{\mathrm{z}}\right), 4.8-5.3 \mathrm{mV} / \mathrm{Nmm} \\
\left(M_{\mathrm{x}}, M_{\mathrm{y}}, M_{\mathrm{z}}\right) \\
\mathrm{CE}: 0.01-0.89 \%\end{array}$ & $\begin{array}{l}\text { Measuring forces } \\
\text { between surgical } \\
\text { tools and soft tissue }\end{array}$ \\
\hline $\begin{array}{l}\text { Yuan et al. } \\
{[53]}\end{array}$ & ERSG (16) & $\begin{array}{l}\text { Dual cross-beam (3DOF-B and } \\
3 \text { DOF-C) connected at centre } \\
\text { platform }\end{array}$ & $\begin{array}{l}\text { Diameter }=50 \mathrm{~mm} \\
\text { (overall), Height }= \\
12 \mathrm{~mm} \text { (overall) }\end{array}$ & $\begin{array}{l}F_{\mathrm{x}}=F_{\mathrm{y}}=400 \mathrm{~N}, F_{\mathrm{z}}= \\
1000 \mathrm{~N}, M_{\mathrm{x}}=M_{\mathrm{y}}=20 \\
\mathrm{Nm}, M_{\mathrm{z}}=10 \mathrm{Nm}\end{array}$ & $\begin{array}{l}\mathrm{S}: 8.9-15.9 \mu \mathrm{V} / \mathrm{N}\left(F_{\mathrm{y}}\right. \\
\left.F_{\mathrm{z}}\right), 813.6-2260 \mu \mathrm{V} / \mathrm{Nm} \\
\left(M_{\mathrm{x}}, M_{\mathrm{z}}\right) \\
\mathrm{NE}: 0.2-0.62 \% \\
\mathrm{HE}: 0.26-0.73 \% \\
\mathrm{CE}: 2.23-3 \%\end{array}$ & $\begin{array}{l}\text { Human gait analysis; } \\
\text { Humanoid robot foot }\end{array}$ \\
\hline
\end{tabular}

${ }^{\mathrm{a}}$ Measurement ranges as reported by the respective authors or deduced from calibration plots

${ }^{\mathrm{b}}$ Measurement particulars as reported by the respective authors; $\mathrm{R}=$ resolution, $\mathrm{S}=$ sensitivity, $\mathrm{NE}=$ nonlinearity error, $\mathrm{HE}=$ hysteresis error, $\mathrm{RE}=$ repeatability error, $\mathrm{CE}=$ coupling error, $\mathrm{A}=$ accuracy

'Studies that do not refer to a specific application for the development of the respective sensor are listed here as 'general sensor development' 
Table 3 Summary of column-type force sensors documented in the literature

\begin{tabular}{|c|c|c|c|c|c|c|}
\hline Reference & $\begin{array}{l}\text { Strain } \\
\text { sensing } \\
\text { (number of } \\
\text { sensors) }\end{array}$ & Construction comments & Sensor size & Measurement range $\mathrm{a}^{\mathrm{a}}$ & $\begin{array}{l}\text { Measurement } \\
\text { resolution }^{b}\end{array}$ & Application $^{\mathfrak{c}}$ \\
\hline Berme et al. [1] & ERSG (-) & $\begin{array}{l}\text { Tubular cylinder with end } \\
\text { flanges, machined from } \\
\text { solid bar }\end{array}$ & $\begin{array}{l}\text { Cylinder inner diameter }= \\
26 \mathrm{~mm} \text {, wall thickness }= \\
2.3 \mathrm{~mm} \text {, length }=56 \mathrm{~mm} \\
\text { (overall) }\end{array}$ & $\begin{array}{l}F_{\mathrm{x}}=F_{\mathrm{y}}=100 \mathrm{~N}, F_{\mathrm{z}}= \\
1500 \mathrm{~N}, M_{\mathrm{x}}=150 \mathrm{Nm}, \\
M_{\mathrm{y}}=100 \mathrm{Nm}, M_{\mathrm{z}}=20 \\
\mathrm{Nm}\end{array}$ & - & $\begin{array}{l}\text { Biomechanical analysis of } \\
\text { human gait within a } \\
\text { prosthesis }\end{array}$ \\
\hline $\begin{array}{l}\text { Byrne and } \\
\text { Houlsby [2] }\end{array}$ & ERSG (32) & $\begin{array}{l}\text { Thin-walled aluminium } \\
\text { cylinder with end flanges }\end{array}$ & $\begin{array}{l}\text { Cylinder diameter }=27.5 \\
\text { mm, wall thickness }= \\
0.475 \mathrm{~mm} \text {, cylinder length } \\
=70 \mathrm{~mm}\end{array}$ & - & - & $\begin{array}{l}\text { Force measurement during } \\
\text { shallow foundation } \\
\text { loading experiment }\end{array}$ \\
\hline $\begin{array}{l}\text { Cunningham and } \\
\text { Brown [56] }\end{array}$ & $\operatorname{ERSG}\left(12^{\mathrm{c}}\right)$ & $\begin{array}{l}\text { Tubular cylinder with end } \\
\text { flanges, machined from } \\
\text { solid bar }\end{array}$ & $\begin{array}{l}\text { Cylinder inner diameter }= \\
5 / 8 \text { in, wall thickness }= \\
1 / 32 \text { in, cylinder length }= \\
5 \text { in }\end{array}$ & Composite sensor ${ }^{\mathrm{d}}$ & - & $\begin{array}{l}\text { Force plate for } \\
\text { measurement of forces } \\
\text { between ground and foot } \\
\text { during walking }\end{array}$ \\
\hline Kim et al. [79] & ERSG (16) & Solid steel cylinder & $\begin{array}{l}\text { Diameter }=28.1 \mathrm{~mm} \text {, } \\
\text { length }=56.2 \mathrm{~mm}\end{array}$ & $\begin{array}{l}F_{\mathrm{x}}=F_{\mathrm{y}}=6.1 \mathrm{kN}, F_{\mathrm{z}}= \\
50 \mathrm{kN}, M_{\mathrm{x}}=M_{\mathrm{y}}= \\
228.5 \mathrm{Nm}, M_{\mathrm{z}}=174.1 \\
\mathrm{Nm}\end{array}$ & $\begin{array}{l}\text { NE: } 0.03-0.17 \% \\
\text { HE: } 0.01-0.15 \% \\
\text { RE: } 0.03-0.15 \%\end{array}$ & $\begin{array}{l}\text { General sensor } \\
\text { development }\end{array}$ \\
\hline Paul [57] & $\operatorname{SSG}\left(12^{\mathrm{c}}\right)$ & $\begin{array}{l}\text { Tubular cylinder, drawn } \\
\text { cylinder welded to end } \\
\text { flanges }\end{array}$ & $\begin{array}{l}\text { Cylinder inner diameter }= \\
5 / 8 \text { in, wall thickness }= \\
1 / 32 \text { in, cylinder length }= \\
5.25 \text { in (overall) }\end{array}$ & Composite sensor ${ }^{\mathrm{d}}$ & - & $\begin{array}{l}\text { Force plate for } \\
\text { measurement of forces } \\
\text { between ground and foot } \\
\text { during walking }\end{array}$ \\
\hline $\begin{array}{l}\text { Van Brussel et al. } \\
\text { [37] }\end{array}$ & ERSG (-) & $\begin{array}{l}\text { Four flexural aluminium } \\
\text { strips between rigid rings }\end{array}$ & $\begin{array}{l}\text { Diameter }=170 \mathrm{~mm} \\
\text { (overall), length }=60 \mathrm{~mm} \\
\text { (overall) }\end{array}$ & $\begin{array}{l}F_{\mathrm{x}}=F_{\mathrm{y}}=F_{\mathrm{z}}=200 \mathrm{~N}, \\
M_{\mathrm{x}}=M_{\mathrm{y}}=100 \mathrm{Nm}, M_{\mathrm{z}} \\
=20 \mathrm{Nm}\end{array}$ & $\mathrm{R}: 0.1-0.2 \%$ & $\begin{array}{l}\text { Robot control in deburring } \\
\text { applications }\end{array}$ \\
\hline van der Laag [15] & $\begin{array}{l}\text { ERSG (32); } \\
\text { FBG (46) }\end{array}$ & $\begin{array}{l}\text { Large hollow steel cylinder } \\
\text { with end flanges, }\end{array}$ & $\begin{array}{l}\text { Cylinder outer diameter }= \\
170 \mathrm{~mm} \text {, length }=520 \mathrm{~mm} \\
\text { (overall) }\end{array}$ & $\begin{array}{l}F_{\mathrm{x}}=F_{\mathrm{y}}= \pm 200 \mathrm{kN}, F_{\mathrm{z}} \\
= \pm 1000 \mathrm{kN}, M_{\mathrm{z}}= \pm \\
100 \mathrm{kNm}\end{array}$ & $\mathrm{NE}:<0.4 \%$ & $\begin{array}{l}\text { To assess performance of } \\
6 \text {-axis fatigue test loading } \\
\text { rig }\end{array}$ \\
\hline
\end{tabular}


instrumentation on inside

and outside surface

${ }^{a}$ Measurement ranges as reported by the respective authors or deduced from calibration plots

${ }^{\mathrm{b}}$ Measurement particulars as reported by the respective authors; $\mathrm{R}=$ resolution, $\mathrm{S}=$ sensitivity, $\mathrm{NE}=$ nonlinearity error, $\mathrm{HE}=\mathrm{hysteresis}$ error, $\mathrm{RE}=$ repeatability error, $\mathrm{CE}=$ coupling error, $\mathrm{A}=$ accuracy

'Studies that do not refer to a specific application for the development of the respective sensor are listed here as 'general sensor development'

${ }^{\mathrm{d} C}$ Columns used in 'composite sensor' comprising a plate supported by four columns 
Table 4 Summary of Stewart platform force sensors documented in the literature

\begin{tabular}{|c|c|c|c|c|c|c|}
\hline Reference & $\begin{array}{l}\text { Strain } \\
\text { sensing } \\
\text { (number of } \\
\text { sensors) }\end{array}$ & Construction comments & Sensor size & Measurement range $^{\mathrm{a}}$ & $\begin{array}{l}\text { Measurement } \\
\text { resolution }^{b}\end{array}$ & Application $^{\mathrm{c}}$ \\
\hline $\begin{array}{l}\text { Bhavikatti et al. } \\
\text { [70] }\end{array}$ & ERSG (24) & $\begin{array}{l}\text { Near-singularity design, } \\
\text { flexural joints, ring -shaped } \\
\text { strain sensing elements in } \\
\text { legs }\end{array}$ & $\begin{array}{l}\text { Diameter }=80 \mathrm{~mm} \\
\text { (overall), height }=47 \mathrm{~mm} \\
\text { (overall) }\end{array}$ & $\begin{array}{l}F_{\mathrm{x}}=F_{\mathrm{y}}=50 \mathrm{~N}, F_{\mathrm{z}}= \\
200 \mathrm{~N}, M_{\mathrm{x}}=M_{\mathrm{y}}=M_{\mathrm{z}}= \\
10000 \mathrm{Nmm}\end{array}$ & - & Robot wrist force sensor \\
\hline Dai and Kerr [66] & ERSG (-) & $\begin{array}{l}\text { Pretensioned wires for legs } \\
\text { connected to strain gauged } \\
\text { cantilevers on the base }\end{array}$ & $\begin{array}{l}\text { Radius to leg mounts on } \\
\text { base }=40 \mathrm{~mm} \text {, Effective } \\
\text { platform height }=49 \mathrm{~mm}\end{array}$ & - & - & $\begin{array}{l}\text { Contact force } \\
\text { measurement for robot } \\
\text { grasping }\end{array}$ \\
\hline $\begin{array}{l}\text { Dwarakanath et al. } \\
\text { [67] }\end{array}$ & ERSG (-) & $\begin{array}{l}\text { Ball and socket joints, } \\
\text { circular leg structures }\end{array}$ & $\begin{array}{l}\text { Base radius }=4.5 \mathrm{~cm} \text {, } \\
\text { height }=8.7 \mathrm{~cm}\end{array}$ & - & $\mathrm{A}:<2 \%$ & Robotics applications \\
\hline $\begin{array}{l}\text { Dwarakanath and } \\
\text { Venkatesh [74] }\end{array}$ & ERSG (24) & $\begin{array}{l}\text { 'Joint-less' design with } \\
\text { deadweight pre-load }\end{array}$ & Height $=57.92 \mathrm{~mm}$ & $\begin{array}{l}\text { ERSG example: } \\
F_{\mathrm{x}}= \pm 73 \mathrm{~N}, F_{\mathrm{y}}= \pm 63 \\
\mathrm{~N}, F_{\mathrm{z}}= \pm 125 \mathrm{~N}, M_{\mathrm{x}}= \\
\pm 3394 \mathrm{Nmm}, M_{\mathrm{y}}= \pm \\
2939 \mathrm{Nmm}, M_{\mathrm{z}}= \pm \\
4899 \mathrm{Nmm}\end{array}$ & $\mathrm{A}:<4.6 \%$ & $\begin{array}{l}\text { General sensor } \\
\text { development }\end{array}$ \\
\hline $\begin{array}{l}\text { Haslinger et al. } \\
\text { [77] }\end{array}$ & FBG (7) & $\begin{array}{l}\text { Steel capillary legs } \\
\text { containing optical fibres } \\
\text { with FBGs }\end{array}$ & $\begin{array}{l}\text { Diameter }=6.4 \mathrm{~mm} \\
\text { (overall), length }=6.5 \mathrm{~mm} \\
\text { (overall) }\end{array}$ & $\begin{array}{l}F_{\mathrm{x}}=F_{\mathrm{y}}=F_{\mathrm{z}}=20 \mathrm{~N}, M_{\mathrm{x}} \\
=M_{\mathrm{y}}=15 \mathrm{Ncm}, M_{\mathrm{z}}= \\
10 \mathrm{Ncm}\end{array}$ & $\begin{array}{l}\text { HE: } 0.03-0.53 \mathrm{~N}\left(F_{\mathrm{x}},\right. \\
\left.F_{\mathrm{y},} F_{\mathrm{z}}\right), 0.05-0.086 \\
\operatorname{Nmm}\left(M_{\mathrm{x}}, M_{\mathrm{y}}, M_{\mathrm{z}}\right) \\
\text { CE: } 1.85 \mathrm{~N}\left(F_{\mathrm{z}}\right), 6.57 \\
\operatorname{Nmm}\left(M_{\mathrm{y}}\right) \\
\mathrm{A}: 94.9 \%\end{array}$ & $\begin{array}{l}\text { Minimally invasive } \\
\text { robotic surgery }\end{array}$ \\
\hline Kang [62] & LVDT (6) & $\begin{array}{l}\text { Legs made from a core, two } \\
\text { springs and an LVDT, with } \\
\text { ball and socket joints }\end{array}$ & - & $\begin{array}{l}F_{\mathrm{x}}= \pm 78 \mathrm{~N}, F_{\mathrm{y}}= \pm 80 \\
\mathrm{~N}, F_{\mathrm{z}}=-180-185 \mathrm{~N} \\
M_{\mathrm{x}}= \pm 9.5 \mathrm{Nm}, M_{\mathrm{y}}= \pm \\
8.9 \mathrm{Nm}, M_{\mathrm{z}}= \pm 13 \mathrm{Nm}\end{array}$ & $\begin{array}{l}\text { NE: } 0.83-1.58 \% \\
\mathrm{~A}: 3.5-7.5 \%\end{array}$ & $\begin{array}{l}\text { General sensor } \\
\text { development }\end{array}$ \\
\hline
\end{tabular}




\begin{tabular}{|c|c|c|c|c|c|c|}
\hline Kim and Lee [76] & FBG (6) & $\begin{array}{l}\text { Legs formed by pre- } \\
\text { tensioned FBGs, with a } \\
\text { central column supporting } \\
\text { platform }\end{array}$ & $\begin{array}{l}\text { Diameter }=50 \mathrm{~mm} \\
\text { (overall), Height }=60 \mathrm{~mm} \\
\text { (overall) }\end{array}$ & $\begin{array}{l}F_{\mathrm{x}}=F_{\mathrm{y}}=F_{\mathrm{z}}=38.52 \mathrm{~N}, \\
M_{\mathrm{x}}=M_{\mathrm{y}}=M_{\mathrm{z}}=963 \\
\mathrm{Nmm}\end{array}$ & - & $\begin{array}{l}\text { Minimally invasive } \\
\text { robotic surgery }\end{array}$ \\
\hline Luo et al. [72] & ERSG (12) & $\begin{array}{l}\text { Thin-walled pipe legs, } \\
\text { coincident ball joints }\end{array}$ & - & - & $\mathrm{NE}: 5.2 \%$ & Robot fingers \\
\hline Müller et al. [75] & FBG (6) & $\begin{array}{l}\text { Polymer sensor, pre- } \\
\text { tensioned FBGs with a } \\
\text { central structure supporting } \\
\text { the platform }\end{array}$ & $\begin{array}{l}\text { Sensor volume }<10 \mathrm{~mm} \times \\
10 \mathrm{~mm} \times 10 \mathrm{~mm}\end{array}$ & $\begin{array}{l}F_{\mathrm{x}}=F_{\mathrm{y}}=10 \mathrm{~N}, F_{\mathrm{z}}=20 \\
\mathrm{~N}, M_{\mathrm{x}}=20 \mathrm{Ncm}, M_{\mathrm{y}}= \\
14 \mathrm{Ncm}, M_{\mathrm{z}}=10 \mathrm{Ncm}\end{array}$ & $\mathrm{R}: 100 \mathrm{mN}\left(F_{\mathrm{z}}\right)$ & $\begin{array}{l}\text { Minimally invasive } \\
\text { robotic surgery }\end{array}$ \\
\hline $\begin{array}{l}\text { Romiti and Sorli } \\
\text { [63]; Sorli and } \\
\text { Zhmud́ [64]; } \\
\text { Ferraresi et al. [65] }\end{array}$ & $\begin{array}{l}\text { Single axis } \\
\text { force } \\
\text { transducers }\end{array}$ & $\begin{array}{l}\text { Single-axis force } \\
\text { transducers in legs, ball } \\
\text { joints }\end{array}$ & $\begin{array}{l}\text { Diameter }=180 \mathrm{~mm} \\
\text { (overall), height }=115 \\
\mathrm{~mm}(\text { overall })\end{array}$ & $\begin{array}{l}F_{\mathrm{x}}=F_{\mathrm{y}}= \pm 87 \mathrm{~N}, F_{\mathrm{z}}= \pm \\
256 \mathrm{~N}, M_{\mathrm{x}}=M_{\mathrm{y}}= \pm \\
60.8 \mathrm{Nm}, M_{\mathrm{z}}=70 \mathrm{Nm}\end{array}$ & A: $0.015-0.4 \%$ & Robotic assembly hand \\
\hline Seibold et al. [71] & ERSG (-) & Flexural hinges & $\begin{array}{l}\text { Base radius }=4.2 \mathrm{~mm}, \\
\text { Leg length }=3.9 \mathrm{~mm}\end{array}$ & $\begin{array}{l}F_{\mathrm{x}}=F_{\mathrm{y}}=F_{\mathrm{z}}=2 \mathrm{~N}, M_{\mathrm{x}} \\
=M_{\mathrm{y}}=M_{\mathrm{z}}=80 \mathrm{Nmm}\end{array}$ & $\begin{array}{l}R: 0.05 \mathrm{~N}\left(F_{\mathrm{x}}, F_{\mathrm{y}}\right), \\
0.25 \mathrm{~N}\left(F_{\mathrm{z}}\right)\end{array}$ & $\begin{array}{l}\text { Minimally invasive } \\
\text { robotic surgery }\end{array}$ \\
\hline Yao et al. [73] & ERSG (-) & $\begin{array}{l}\text { Mechanical joints, pre- } \\
\text { stressed central member }\end{array}$ & $\begin{array}{l}\text { Platform radius }=30 \mathrm{~mm} \text {, } \\
\text { Base radius }=24 \mathrm{~mm}, \text { leg } \\
\text { length }=33 \mathrm{~mm}\end{array}$ & $\begin{array}{l}F_{\mathrm{x}}=F_{\mathrm{y}}=F_{\mathrm{z}}=200 \mathrm{~N} \\
M_{\mathrm{x}}=M_{\mathrm{y}}=1 \mathrm{Nm}, M_{\mathrm{z}}= \\
0.4 \mathrm{Nm}\end{array}$ & $\begin{array}{l}\text { A: } 0.2-0.3 \%\left(F_{\mathrm{x}}, F_{\mathrm{y}},\right. \\
\left.F_{\mathrm{z}}\right), 2-11.9 \%\left(M_{\mathrm{x}},\right. \\
\left.M_{\mathrm{y}}, M_{\mathrm{z}}\right)\end{array}$ & $\begin{array}{l}\text { General sensor } \\
\text { development }\end{array}$ \\
\hline Zhenlin et al. [68] & ERSG (24) & $\begin{array}{l}\text { Cube-shaped platform with } \\
\text { legs arranged on three } \\
\text { orthogonal sides, flexural } \\
\text { joints }\end{array}$ & $\begin{array}{l}\text { Diameter }=42 \mathrm{~mm} \\
\text { (overall), height }=21 \mathrm{~mm} \\
\text { (overall) }\end{array}$ & - & - & Robotics applications \\
\hline
\end{tabular}

${ }^{\mathrm{a}}$ Measurement ranges as reported by the respective authors or deduced from calibration plots

${ }^{\mathrm{b}}$ Measurement particulars as reported by the respective authors; $\mathrm{R}=$ resolution, $\mathrm{S}=$ sensitivity, $\mathrm{NE}=$ nonlinearity error, $\mathrm{HE}=$ hysteresis error, $\mathrm{RE}=$ repeatability error, $\mathrm{CE}=$ coupling error, $\mathrm{A}=$ accuracy

'Studies that do not refer to a specific application for the development of the respective sensor are listed here as 'general sensor development' 


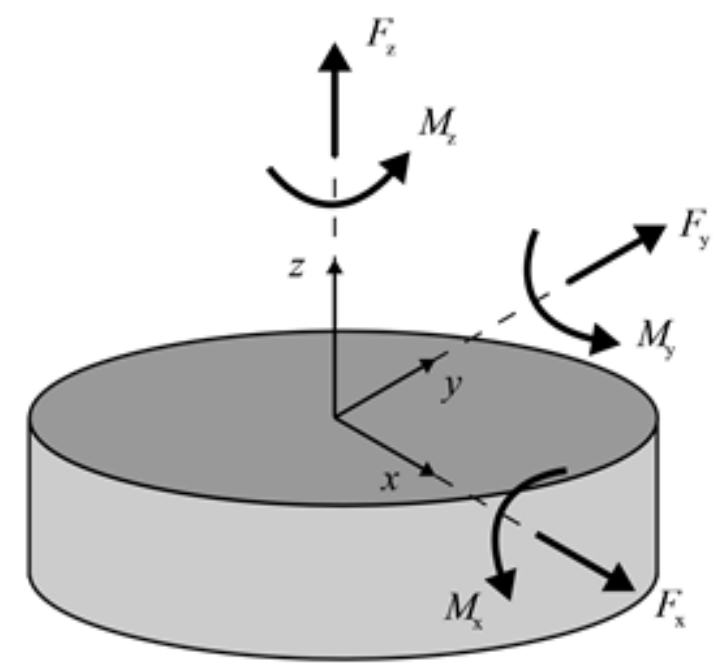

Figure $13 \mathrm{D}$ cartesian coordinate system adopted for force sensor analysis, showing the six general force and moment components 


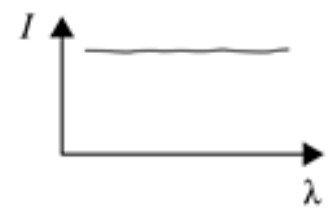

Incident light
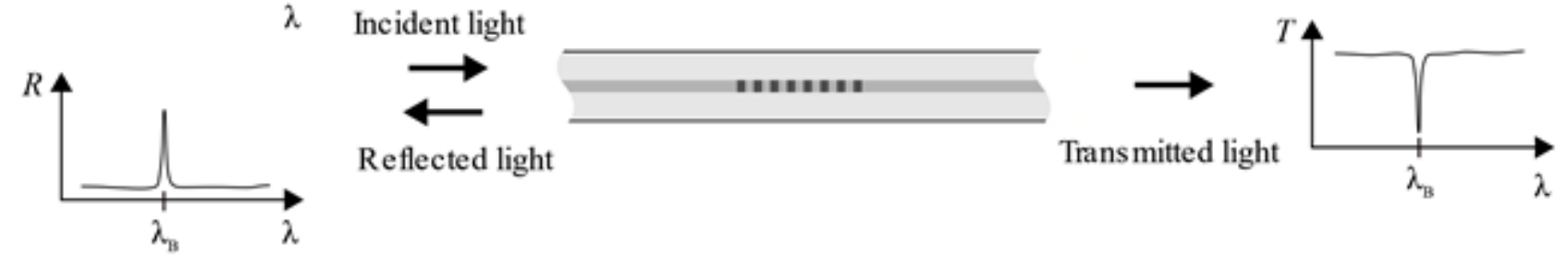

Figure 2 Illustration of the optical behaviour of a typical uniform FBG, showing indicative incident, reflected and transmitted light spectra 


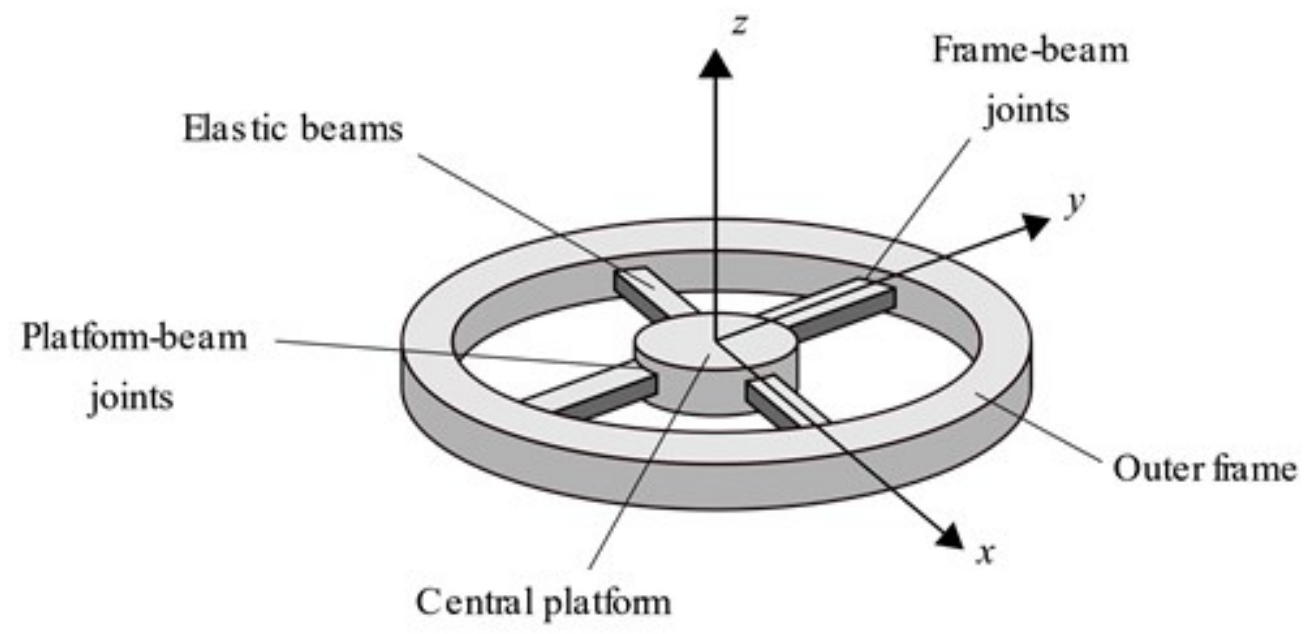

Figure 3 Illustration of a conventional cross-beam force sensor, showing the main elements of the structure 


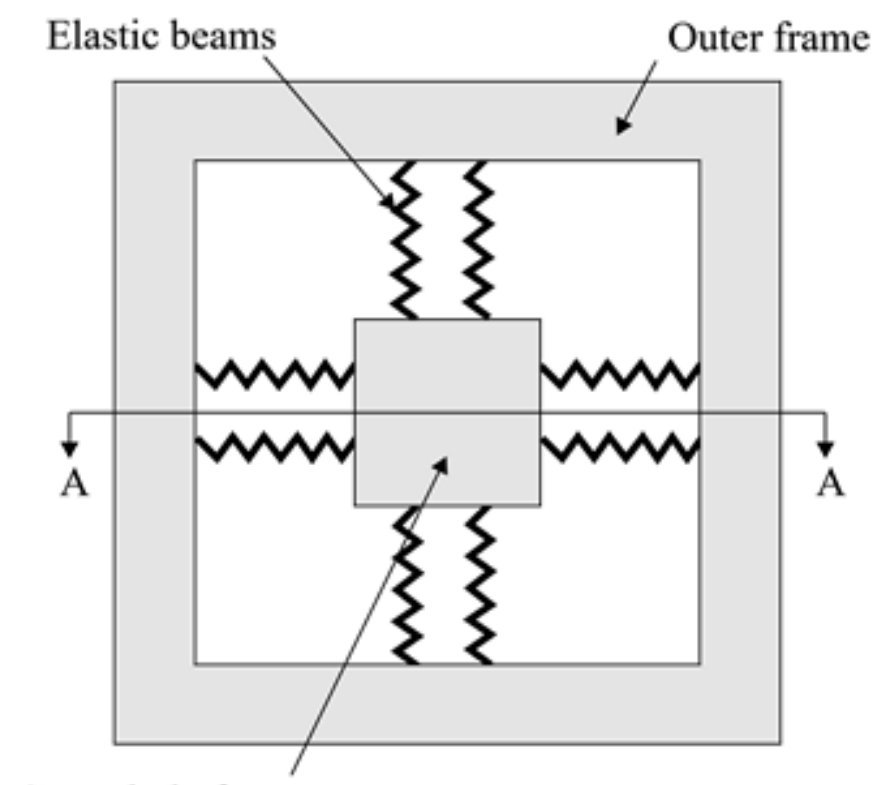

Central platform

(a)

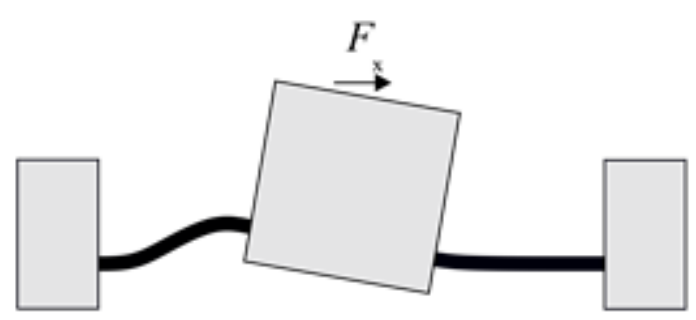

(b)

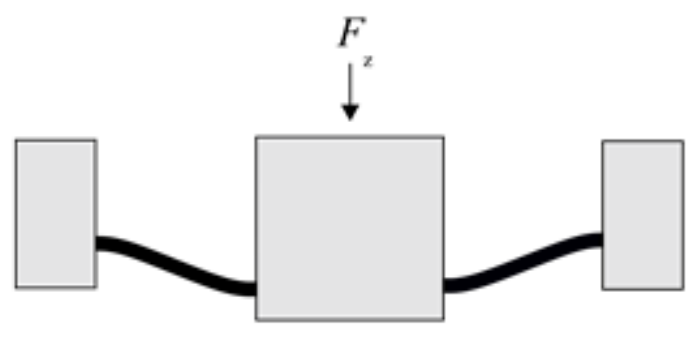

(c)

Figure 4 Schematic of a 3DOF-A cross-beam sensor proposed in [25]: (a) Plan view, (b) Secion AA showing the exaggerated deformed shape under $F_{\mathrm{x}}$ loading and (c) Section A-A showing the exaggerated deformed shape under $F_{\mathrm{z}}$ loading 


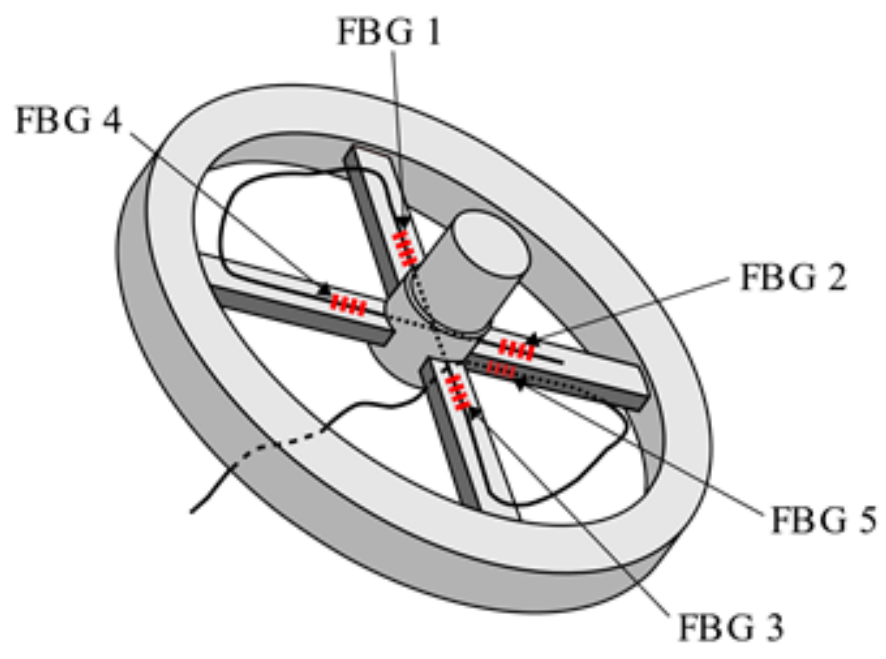

Figure 5 Schematic of a 3DOF-A cross-beam force sensor instrumented with five FBGs documented in [26] 


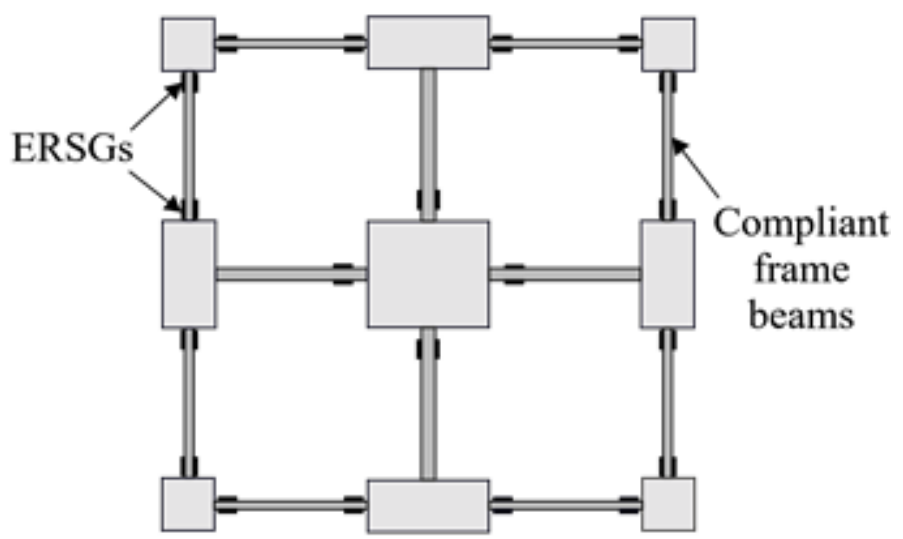

(a)

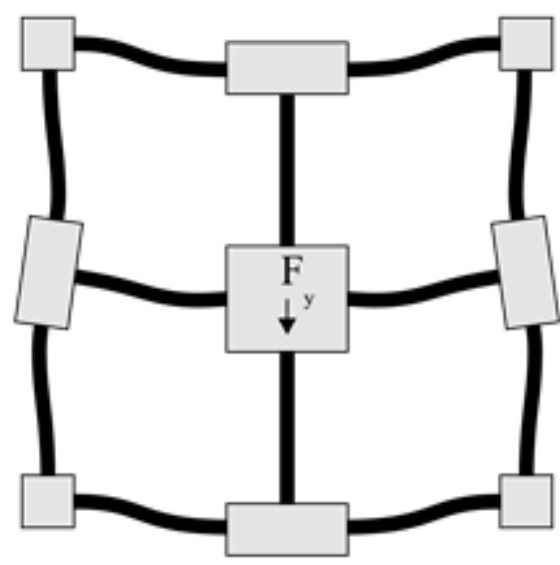

(b)

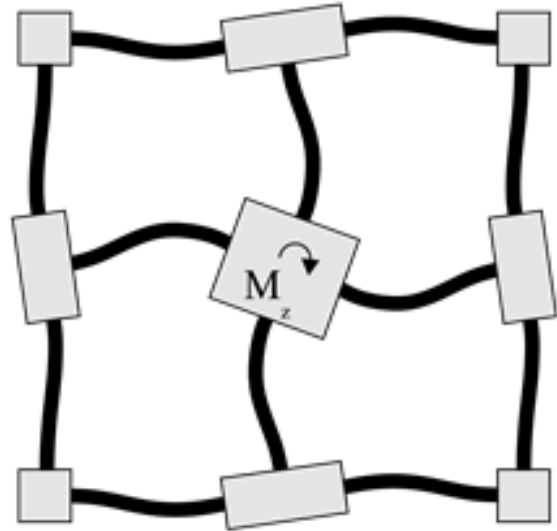

(c)

Figure 6 Three DOF cross-beam force sensor design proposed in [27] involving the use of highly compliant elastic beam members: (a) structure showing locations of ERSGs, (b) exaggerated deformed shape of structure under $F_{\mathrm{y}}$ loading and (c) exaggerated deformed shape of structure under $M_{\mathrm{z}}$ loading 


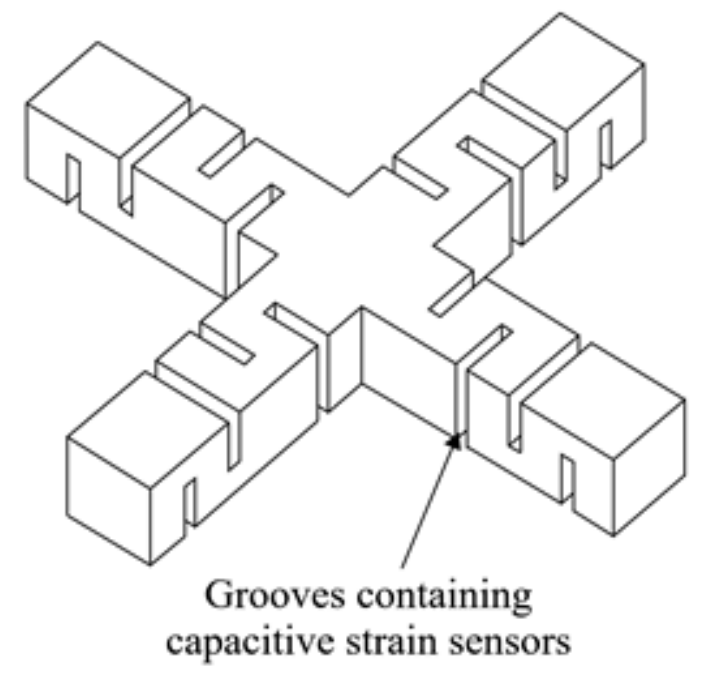

Figure 7 Six DOF cross-beam force sensor proposed in [31] showing grooves fabricated for capacitive strain-sensing 


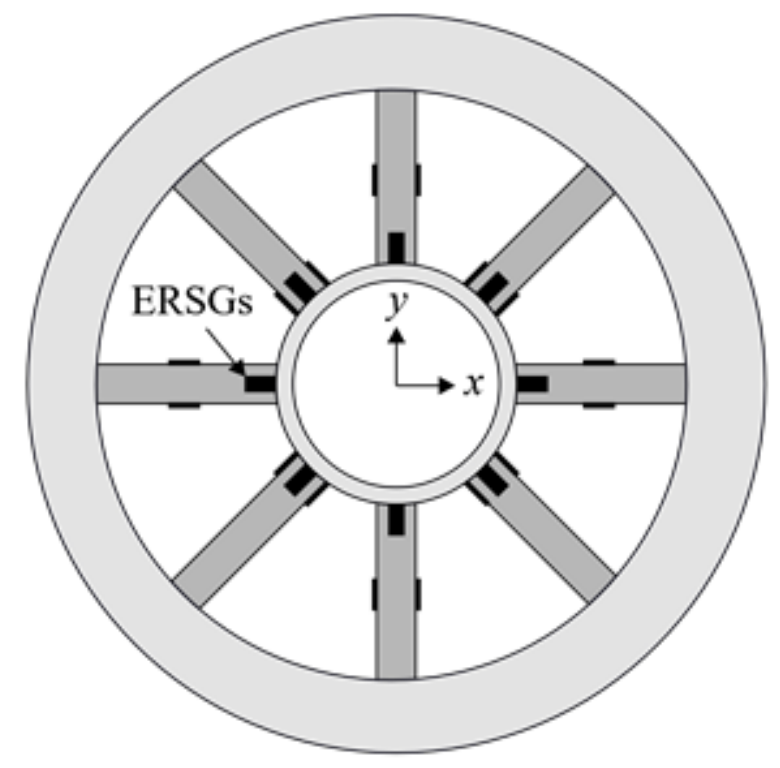

Figure 8 Schematic of a double-cross beam design for wheel force measurement proposed in [34] showing ERSG locations 


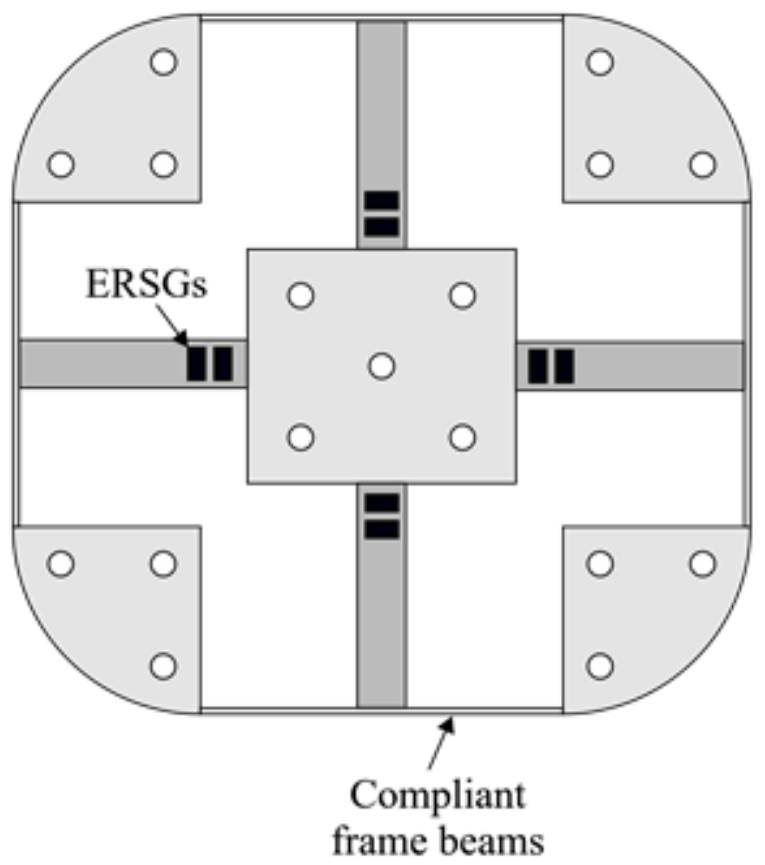

Figure 9 Illustration of a flexible-jointed six DOF cross-beam design documented in [37], showing highly-compliant plate elements in the outer frame and ERSG locations on the beam members 


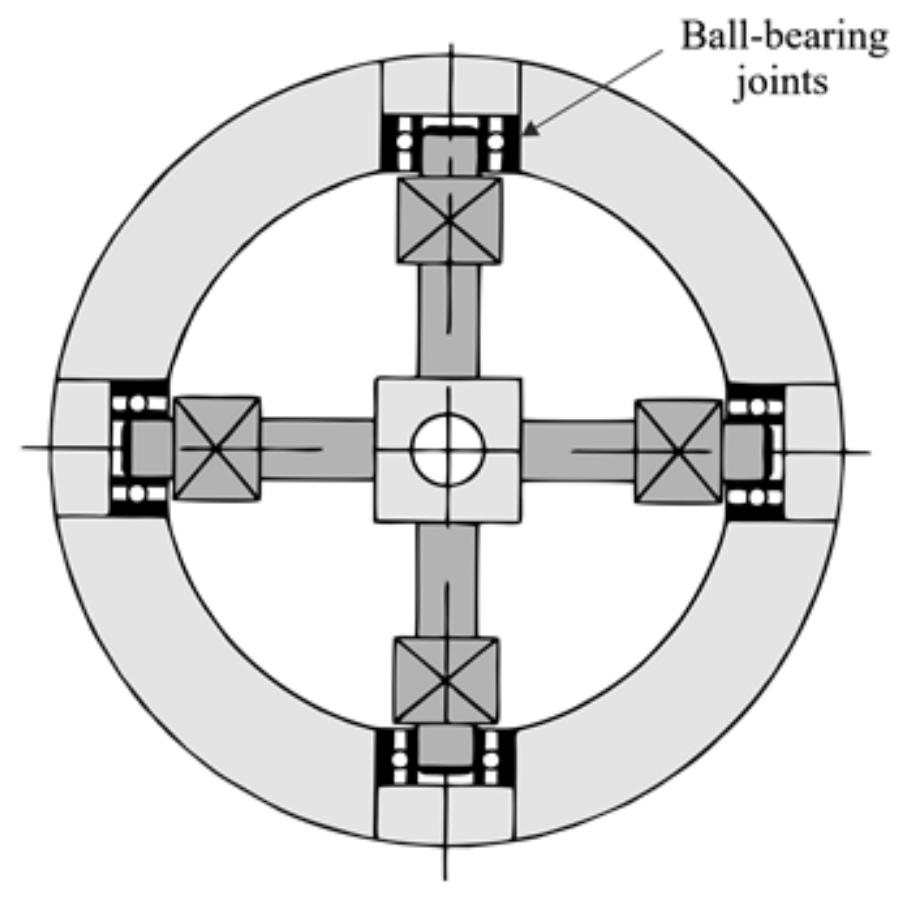

Figure 10 Six DOF cross-beam design proposed in [38] employing ball-bearings at the frame-beam joints 


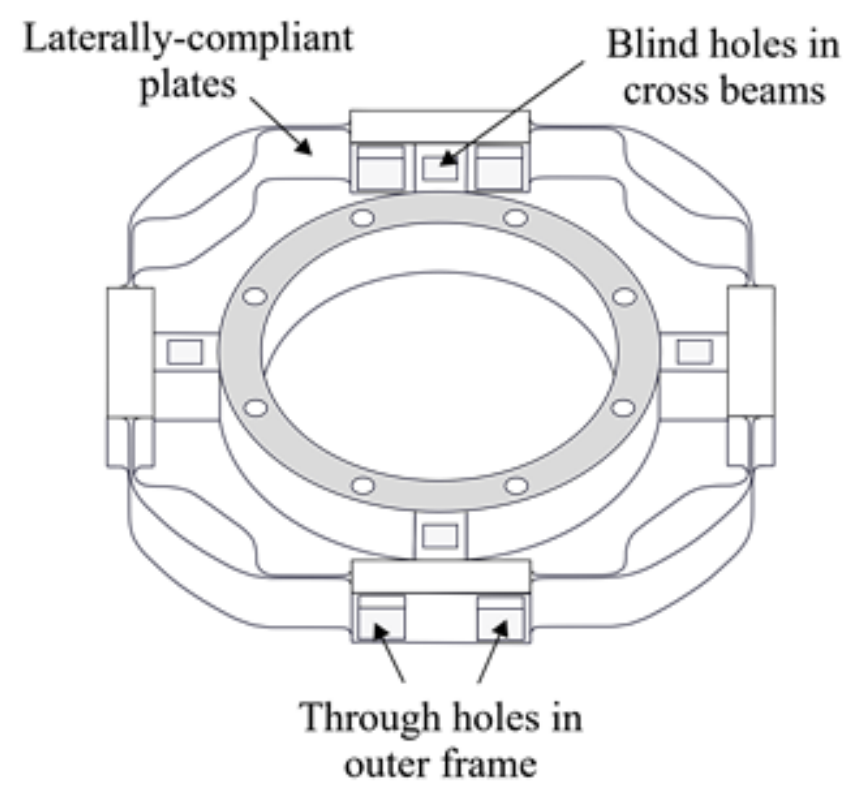

Figure 11 Three-dimensional view of the six DOF cross-beam sensor structure proposed in [46] involving laterally-compliant plates in the outer frame and blind holes and through holes in the beams and frame respectively to increase the load sensitivity 


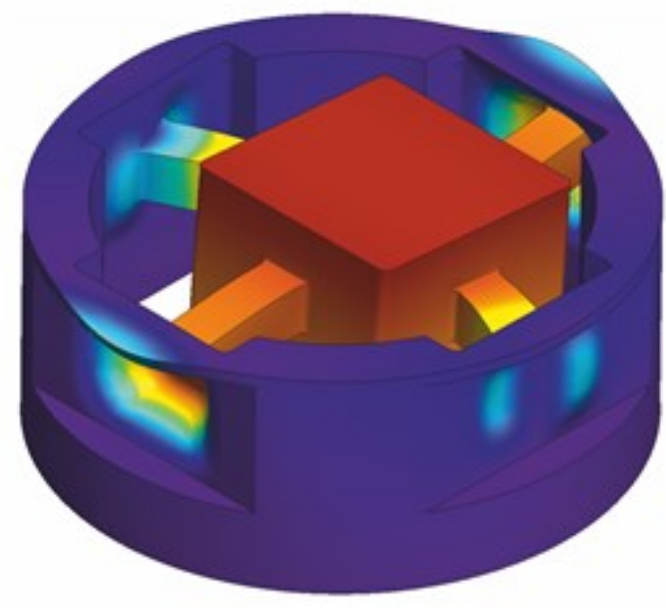

(a)

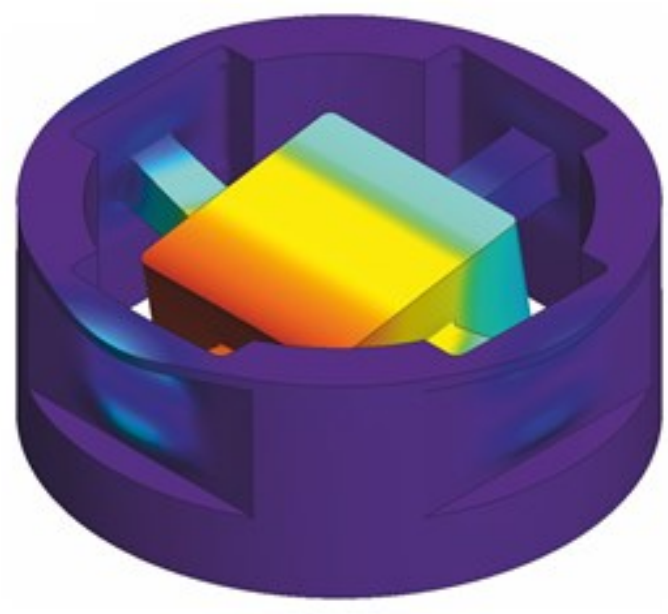

(c)

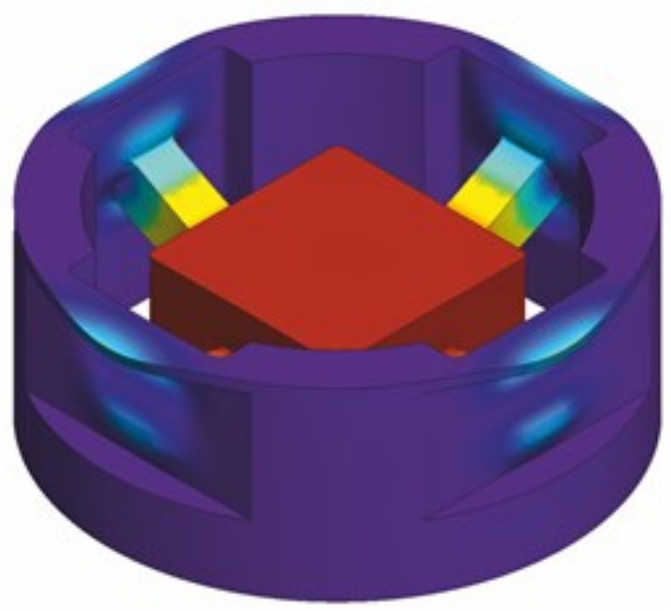

(b)

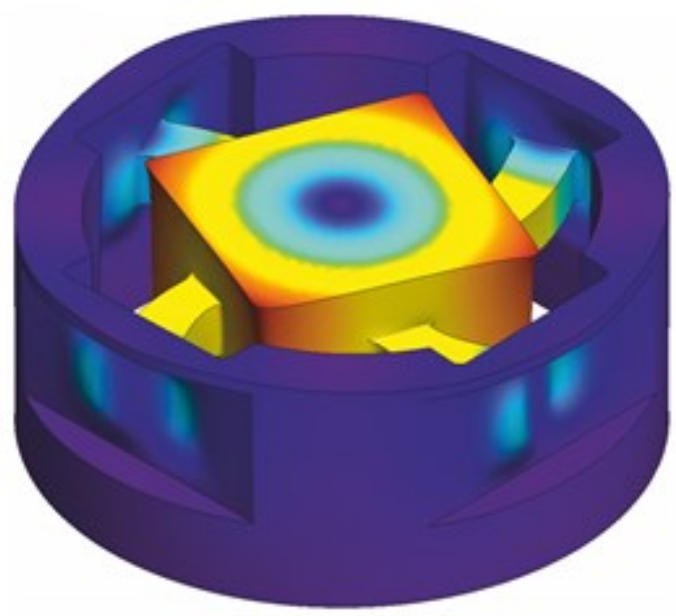

(d)

Figure 12 Illustration of the deformed shape of the flexible-jointed six DOF cross-beam sensor documented in [30] for (a) $F_{\mathrm{y}}$, (b) $F_{\mathrm{z}}$, (c) $M_{\mathrm{x}}$, and (d) $M_{\mathrm{z}}$ loading. Contours denote resultant displacements 


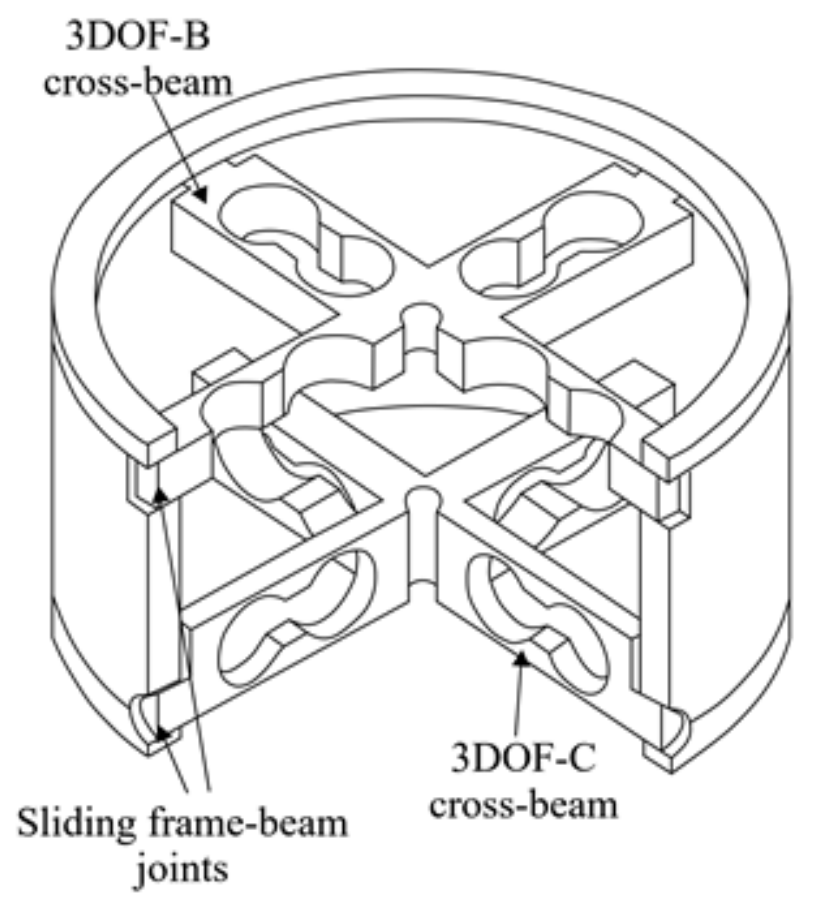

Figure 13 Dual-layer six DOF cross-beam force sensor proposed in [54] comprising an upper 3DOF-B cross-beam and a lower 3DOF-C cross-beam. The cross-beams are connected to the outer frame using sliding joints 


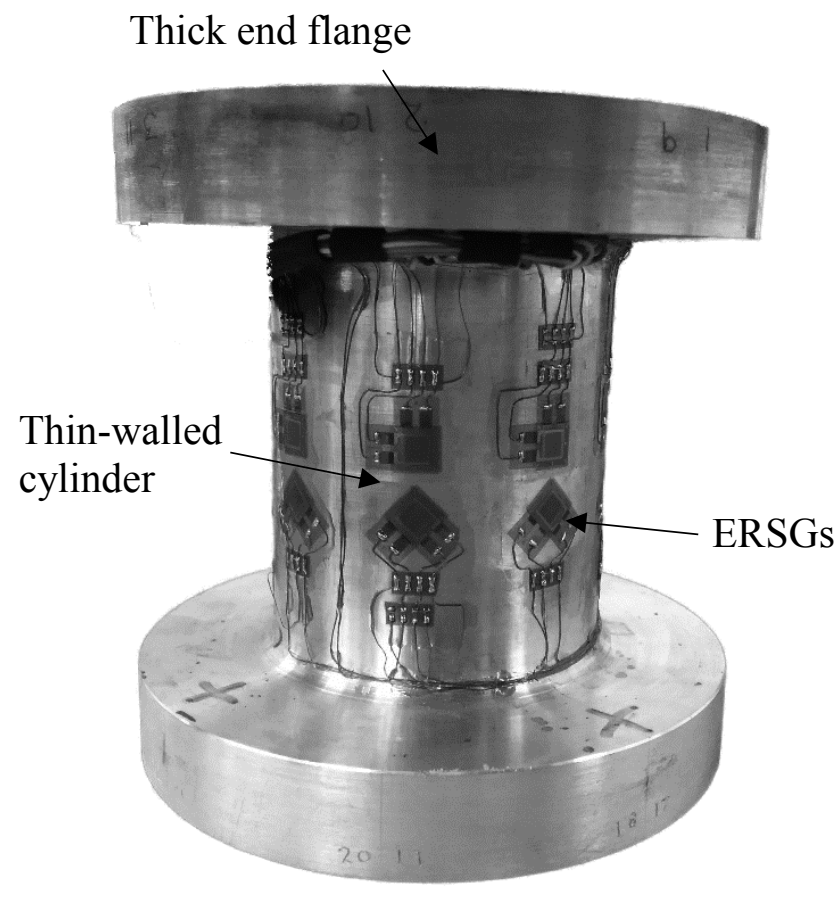

Figure 14 View of column-type load cell developed in [2] showing locations of ERSGs mounted on outer surface of the thin-walled cylinder sensor body 


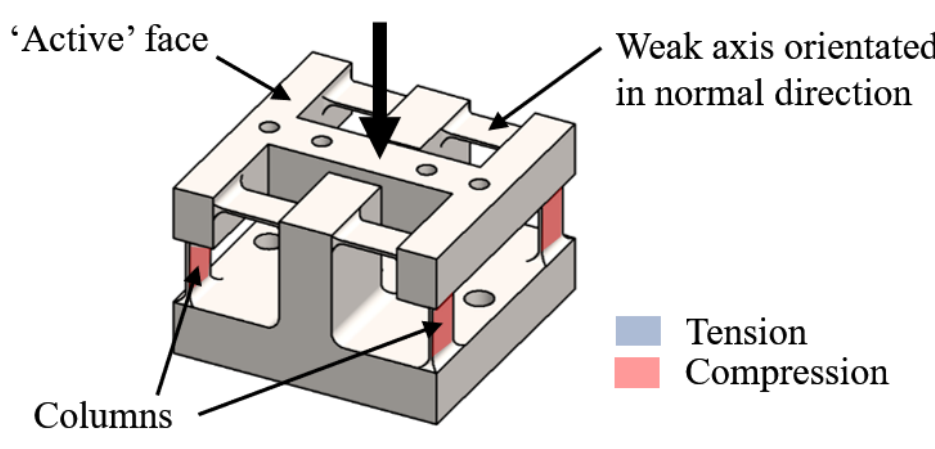

(a)

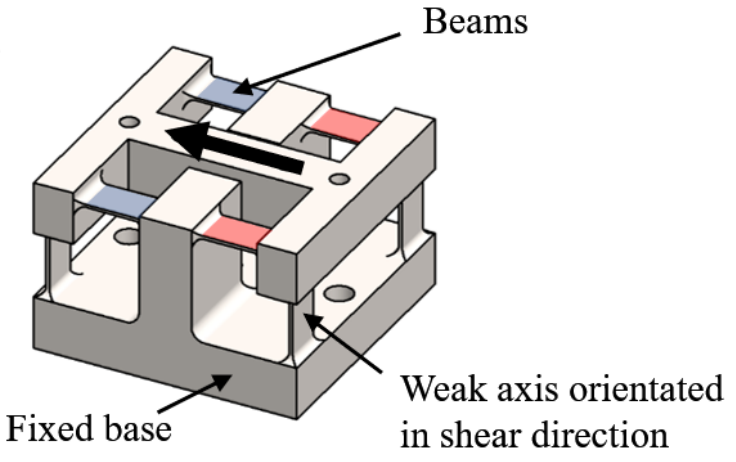

(b)

Figure 15 Beam-column force sensor proposed in [58] showing primary locations of tension and compression in the beams and columns under (a) $F_{\mathrm{z}}$ loading and (b) $F_{\mathrm{x}}$ loading 


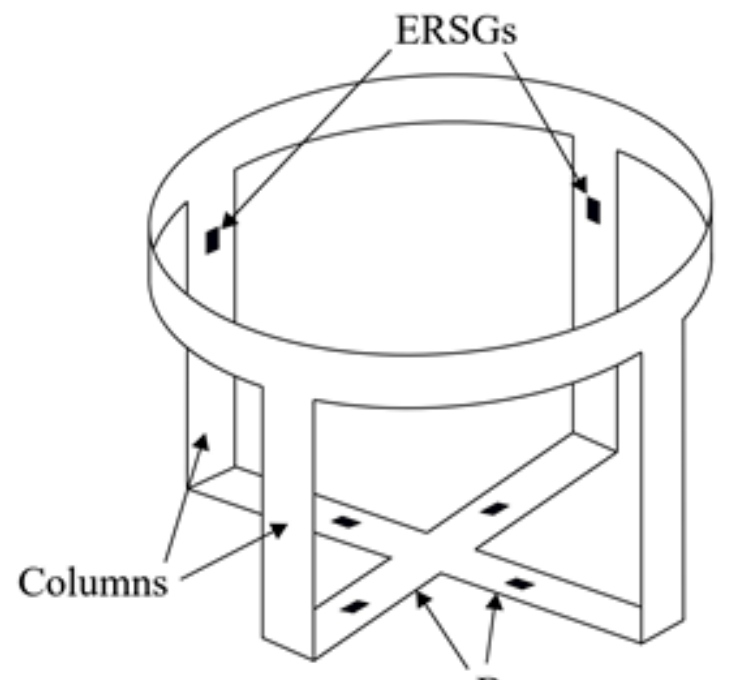

Beams

Figure 16 Schematic of the beam-column sensor design proposed in [60] 


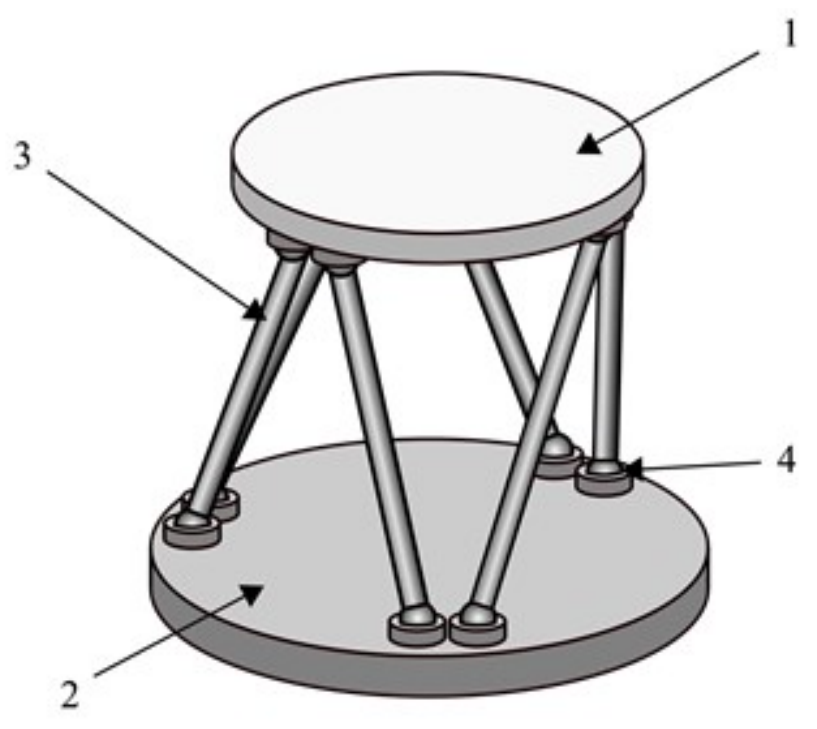

Figure 17 Illustration of a Stewart platform structure, showing the platform (1), fixed base (2), legs

(3) and joints (4) 


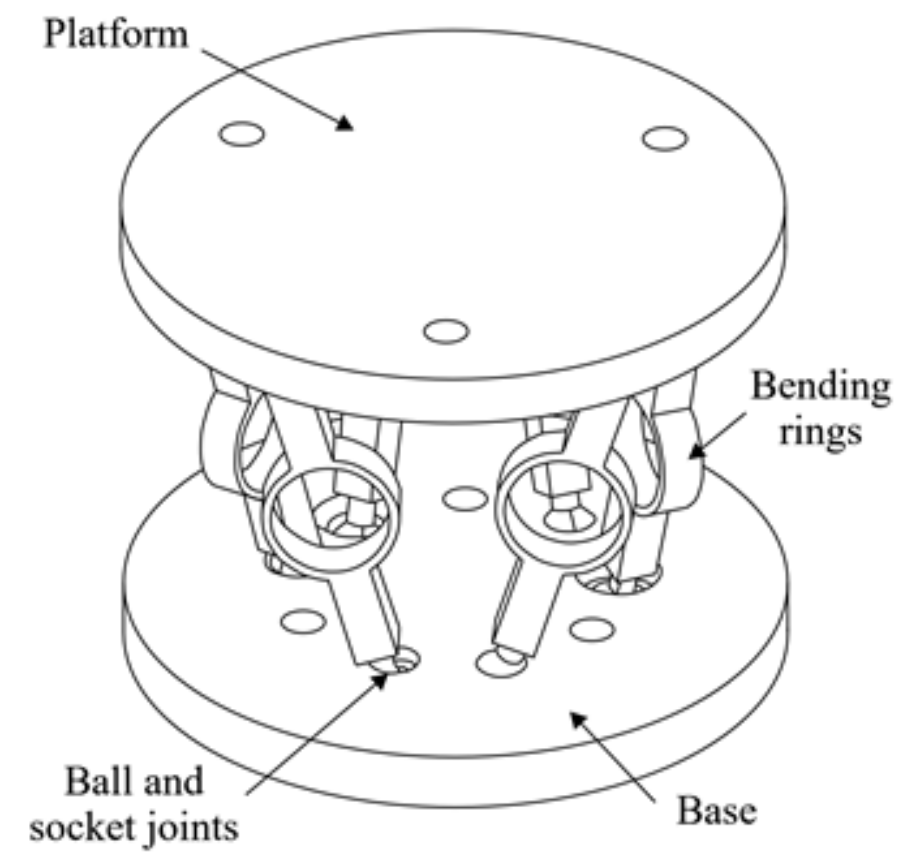

Figure 18 Stewart platform design proposed in [67] showing the strain gauged bending rings in the platform legs and the use of ball-and socket joints to connect the legs to the platform and base 


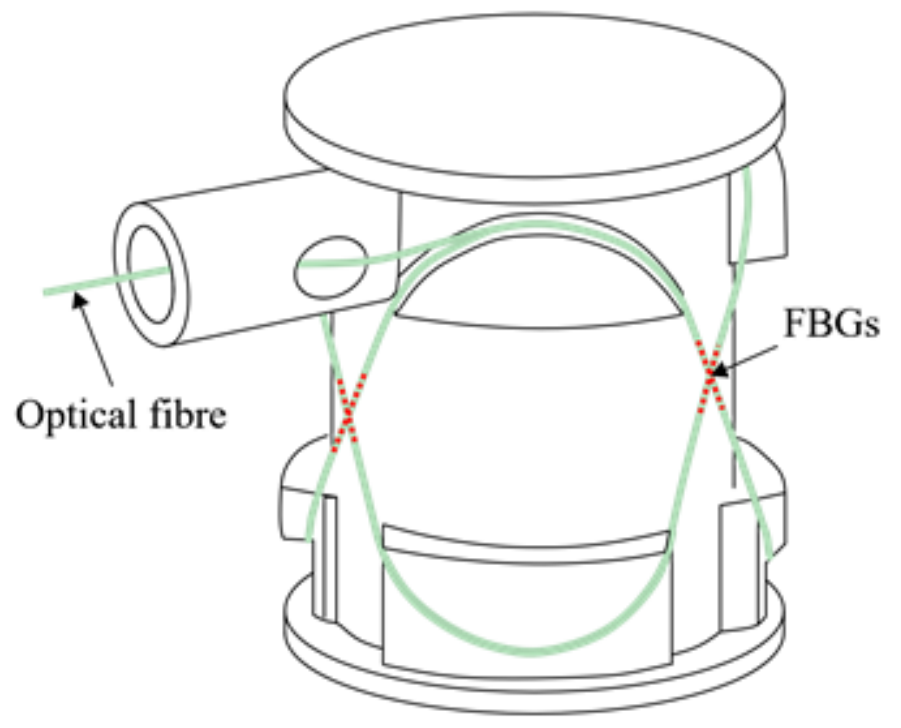

Figure 19 Stewart platform design using FBGs proposed in [75] 